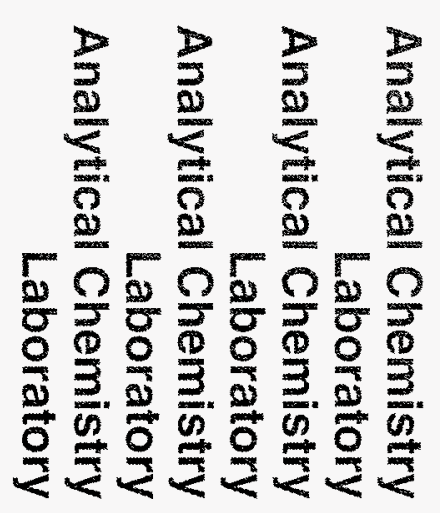

9
8
8
8
8
8
8

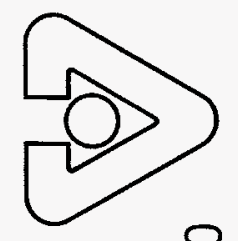

호응 공 옥 은

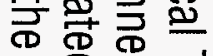
등하융

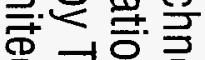
홍 걱을 응 ल ळळ 可 ᄃํㅇ 㫣包包 ○通 임 옹 告 愛 을 운 备 옹을 m응 高 蒠 盯 음 م

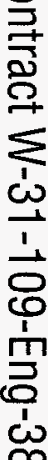

19980528043

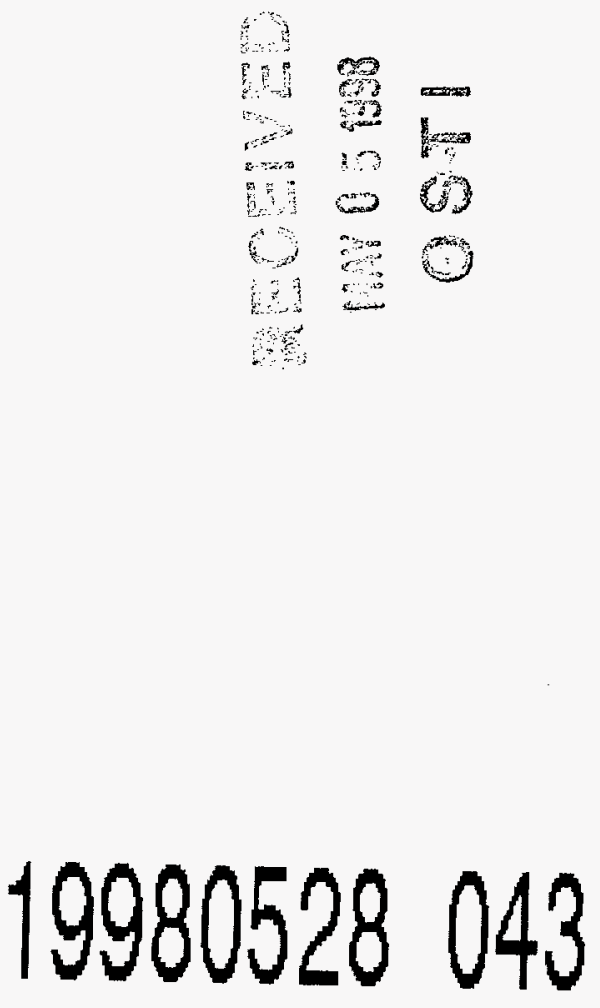

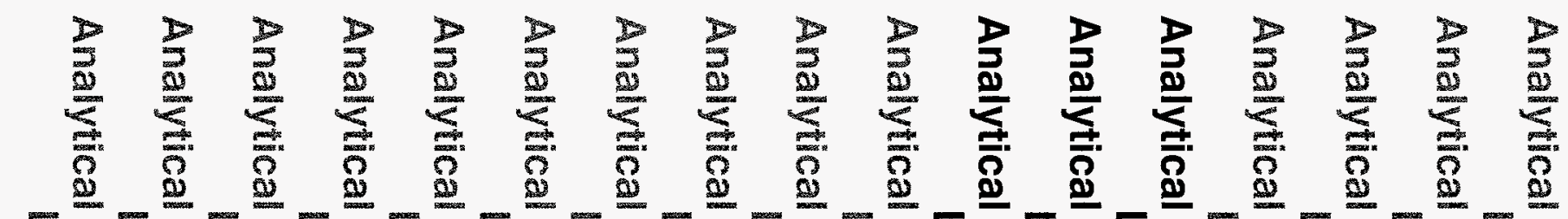

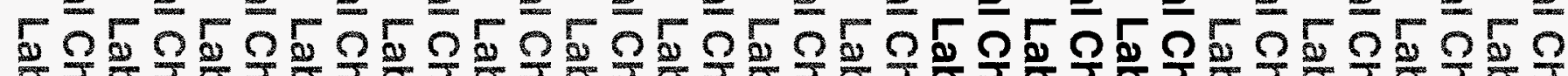


ఏ.



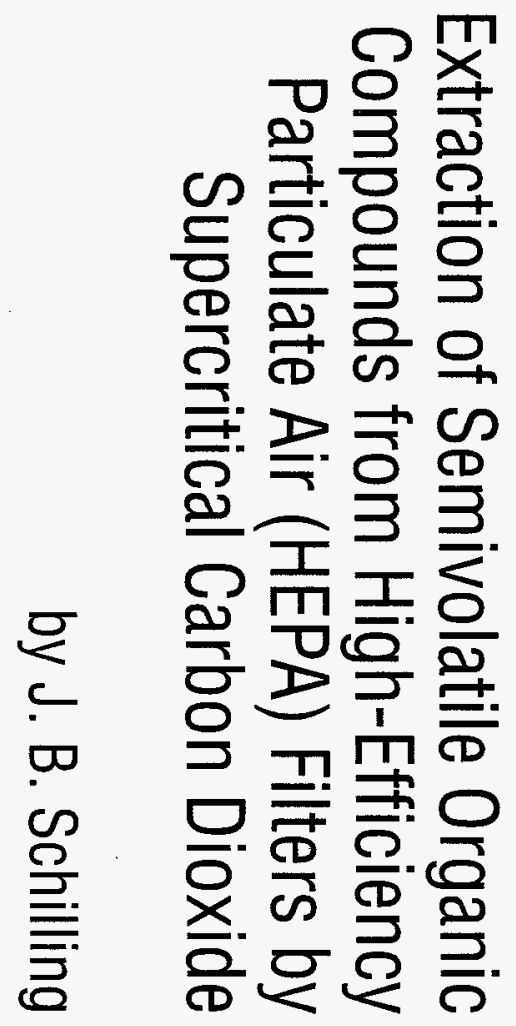


Argonne National Laboratory, with facilities in the states of Illinois and Idaho, is owned by the United States government, and operated by The University of Chicago under the provisions of a contract with the Department of Energy.

\section{DISCLAIMER}

This report was prepared as an account of work sponsored by an agency of the United States Government. Neither the United States Government nor any agency thereof, nor any of their employees, makes any warranty, express or implied, or assumes any legal liability or responsibility for the accuracy, completeness, or usefulness of any information, apparatus, product, or process disclosed, or represents that its use would not infringe privately owned rights. Reference herein to any specific commercial product, process, or service by trade name, trademark, manufacturer, or otherwise, does not necessarily constitute or imply its endorsement, recommendation, or favoring by the United States Government or any agency thereof. The views and opinions of authors expressed herein do not necessarily state or reflect those of the United States Government or any agency thereof.

Reproduced from the best available copy.

Available to DOE and DOE contractors from the

Office of Scientific and Technical Information

P.O. Box 62

Oak Ridge, TN 37831

Prices available from (423) 576-8401

Available to the public from the

National Technical Information Service

U.S. Department of Commerce

5285 Port Royal Road

Springfield, VA 22161 
ANL/ACL-97/6

ARGONNE NATIONAL LABORATORY

9700 South Cass Avenue

Argonne, Illinois 60439

\section{EXTRACTION OF SEMIVOLATILE ORGANIC COMPOUNDS FROM HIGH-EFFICIENCY PARTICULATE AIR (HEPA) FILTERS \\ BY SUPERCRITICAL CARBON DIOXIDE}

by

J. Bruce Schilling

Analytical Chemistry Laboratory

Chemical Technology Division

DISTRIBUTION OF THIS DOCUMENT IS UNLIMTED

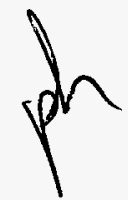




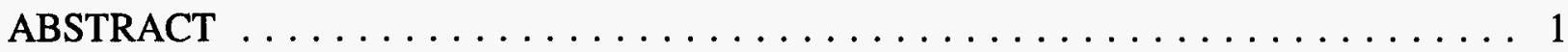

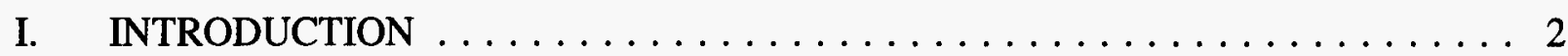

II. EXPERIMENTAL $\ldots \ldots \ldots \ldots \ldots \ldots \ldots \ldots \ldots \ldots \ldots \ldots \ldots \ldots \ldots \ldots$

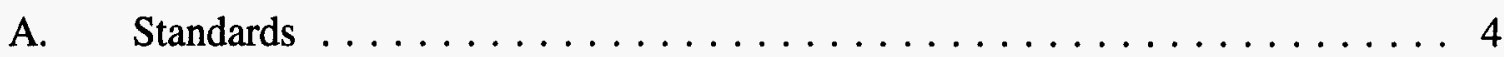

B. Solvents $\ldots \ldots \ldots \ldots \ldots \ldots \ldots \ldots \ldots \ldots \ldots \ldots \ldots$

C. HEPA Filter Spiking $\ldots \ldots \ldots \ldots \ldots \ldots \ldots \ldots \ldots \ldots \ldots$

D. Extraction of Samples Using Supercritical Fluid Extraction $\ldots \ldots \ldots 5$

E. Extraction of HEPA Filters Using Traditional Methods $\ldots \ldots \ldots \ldots 6$

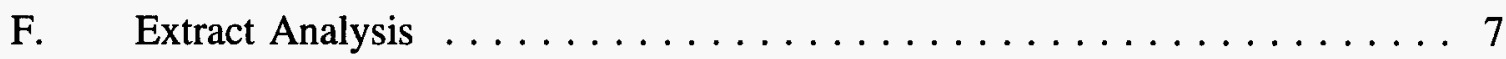

III. $\quad$ RESULTS AND DISCUSSION $\ldots \ldots \ldots \ldots \ldots \ldots \ldots \ldots \ldots$

A. Control Tests and Supercritical Fluid Extraction Method Development . . . 8

B. Comparison of Results from Supercritical Fluid Extraction and Traditional Extraction Methods $\ldots \ldots \ldots \ldots \ldots \ldots \ldots \ldots \ldots$



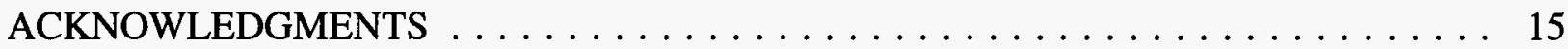

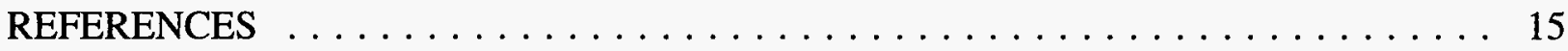




\section{LIST OF FIGURES}

No.

Title

$\underline{\text { Page }}$

1. Schematic Diagram of the Dionex SFE-703 Supercritical

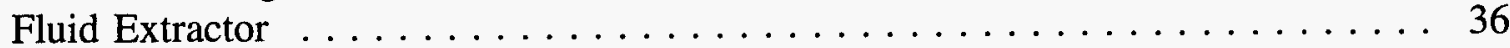

2. Average Percent Recoveries Using $15 \mathrm{~mL}$ of Hexane/Acetone, Methylene

Chloride/Acetone, or Methylene Chloride as the SFE Collection Solvent . . . . . 37

3. Average Percent Recoveries versus Pressure for the Extraction of

Semivolatiles from HEPA Filters Using SFE at $50^{\circ} \mathrm{C} . \ldots \ldots \ldots$

4. Comparison of Average Recoveries versus Temperature for the Extraction

of Semivolatiles from HEPA Filters Using SFE at $400 \mathrm{~atm} \ldots \ldots . \ldots$

5. Variation of Average Percent Recovery across All Compounds

with SFE Extraction Time $\ldots \ldots \ldots \ldots \ldots \ldots \ldots$

6. Comparison between Sonication and SFE for the Extraction

of Phenols from HEPA Filters $\ldots \ldots \ldots \ldots \ldots \ldots \ldots \ldots \ldots$

7. Comparison between Sonication and SFE for the Extraction

of PAHs from HEPA Filters $\ldots \ldots \ldots \ldots \ldots \ldots \ldots \ldots \ldots \ldots$

8. Comparison between Sonication and SFE for the Extraction

of Halocarbons from HEPA Filters $\ldots \ldots \ldots \ldots \ldots \ldots \ldots \ldots$

9. Comparison between Sonication and SFE for the Extraction

of Aromatic Amines from HEPA Filters . . . . . . . . . . . . . . . . . . . . . 44

10. Comparison between Sonication and SFE for the Extraction

of Miscellaneous Nitrogen Compounds from HEPA Filters . . . . . . . . . . . . . 45

11. Comparison between Sonication and SFE for the Extraction

of Miscellaneous Compounds from HEPA Filters $\ldots \ldots \ldots$. . . . . . . . 46

12. Comparison between Sonication and SFE for the Extraction

of Semivolatile Organic Compounds from HEPA Filters

13. Comparison between Soxhlet and SFE for the Extraction

of Phenols from HEPA Filters $\ldots \ldots \ldots \ldots \ldots \ldots \ldots \ldots$

14. Comparison between Soxhlet and SFE for the Extraction

of PAHs from HEPA Filters $\ldots \ldots \ldots \ldots \ldots \ldots \ldots \ldots \ldots \ldots$ 


\section{LIST OF FIGURES (contd)}

No.

Title

Page

15. Comparison between Soxhlet and SFE for the Extraction

of Halocarbons from HEPA Filters $\ldots \ldots \ldots \ldots \ldots \ldots \ldots \ldots \ldots$

16. Comparison between Soxhlet and SFE for the Extraction

of Aromatic Amines from HEPA Filters $\ldots \ldots \ldots \ldots \ldots \ldots \ldots \ldots \ldots$

17. Comparison between Soxhlet and SFE for the Extraction

of Miscellaneous Nitrogen Compounds from HEPA Filters . . . . . . . . . 52

18. Comparison between Soxhlet and SFE for the Extraction of Miscellaneous Compounds from HEPA Filters $\ldots \ldots \ldots \ldots \ldots \ldots$

19. Comparison between Soxhlet and SFE for the Extraction of Semivolatile Organic Compounds from HEPA Filters $\ldots \ldots \ldots \ldots \ldots \ldots 4$

20. Comparison between Soxtec and SFE for the Extraction of Phenols from HEPA Filters $\ldots \ldots \ldots \ldots \ldots \ldots \ldots \ldots \ldots \ldots$

21. Comparison between Soxtec and SFE for the Extraction

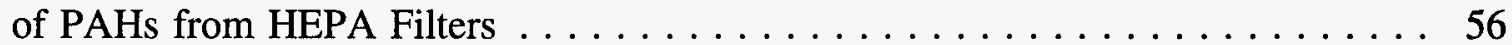

22. Comparison between Soxtec and SFE for the Extraction of Halocarbons from HEPA Filters $\ldots \ldots \ldots \ldots \ldots \ldots \ldots \ldots \ldots$

23. Comparison between Soxtec and SFE for the Extraction of Aromatic Amines from HEPA Filters $\ldots \ldots \ldots \ldots \ldots \ldots \ldots \ldots \ldots$

24. Comparison between Soxtec and SFE for the Extraction of Miscellaneous Nitrogen Compounds from HEPA Filters . . . . . . . . . . 59

25. Comparison between Soxtec and SFE for the Extraction of Miscellaneous Compounds from HEPA Filters $\ldots \ldots \ldots \ldots \ldots \ldots \ldots$

26. Comparison between Soxtec and SFE for the Extraction of Semivolatile Organic Compounds from HEPA Filters 


\section{LIST OF TABLES}

No.

Title

Page

1. RCRA Method 8270 Base/Neutral/Acid Analytes Used in This Study . . . . . . 18

2. Average Semivolatile Recoveries versus Collection Solvent and Solvent Volume for SFE of Spiked Sand . . . . . . . . . . . . . 21

3. Comparison of Average SFE Recoveries for 30- and 45-min Extractions with Methylene Chloride and Hexane/Acetone Extraction Solvents . . . . . . . . 22

4. Comparison of Compound Recoveries between SFE and Traditional Extraction Technique 


\title{
EXTRACTION OF SEMIVOLATILE ORGANIC COMPOUNDS FROM HIGH-EFFICIENCY PARTICULATE AIR (HEPA) FILTERS BY SUPERCRITICAL CARBON DIOXIDE
}

by

\author{
J. Bruce Schilling
}

\begin{abstract}
Supercritical fluid extraction (SFE) using unmodified carbon dioxide has been explored as an alternative method for the extraction of semivolatile organic compounds from high-efficiency particulate air (HEPA) filters. HEPA filters provide the final stage of containment on many exhaust systems in U.S. Department of Energy (DOE) facilities by preventing the escape of chemical and radioactive materials entrained in the exhausted air. The efficiency of the filters is tested by the manufacturer and DOE using dioctylphthalate (DOP), a substance regulated by the U.S. Environmental Protection Agency under the Resource Conservation and Recovery Act. Therefore, the filters must be analyzed for semivolatile organics before disposal.

Ninety-eight acid, base, and neutral semivolatile organics were spiked onto blank HEPA material and extracted using SFE, Soxhlet, automated Soxhlet, and sonication techniques. The SFE conditions were optimized using a Dionex SFE703 instrument. Average recoveries for the 98 semivolatile compounds are $82.7 \%$ for Soxhlet, $74.0 \%$ for sonication, $70.2 \%$ for SFE, and $62.9 \%$ for Soxtec. Supercritical fluid extraction reduces the extraction solvent volume to $10-15 \mathrm{~mL}$, a factor of 20-30 less than Soxhlet and more than 5 times less than Soxtec and sonication. Extraction times of 30-45 min are used compared to $16-18 \mathrm{~h}$ for Soxhlet extraction.
\end{abstract}




\section{INTRODUCTION}

High-efficiency particulate air (HEPA) filters provide the final stage of containment on many exhaust systems in U.S. Department of Energy (DOE) facilities by preventing the escape of chemical and radioactive materials entrained in the exhausted air. The trapping efficiency of the filters is tested, using bis(2-ethylhexylphthalate) (normally referred to as dioctylphthalate or DOP), by both the manufacturer and by DOE, at one of three HEPA test facilities as well as in the installed duct work at various operating laboratories or production facilities. ${ }^{1}$ Dioctylphthalate is a substance regulated by the U.S. Environmental Protection Agency (EPA) under the Resource Conservation and Recovery Act (RCRA). It is considered a hazardous chemical under the State of Washington's Dangerous Waste Regulations, which impacts the acceptance criteria for solid waste sent to the Hanford disposal site. Therefore, the filters must be analyzed for semivolatile organic compounds before disposal.

Traditional extraction techniques for semivolatile organic compounds (SVOCs) include Soxhlet, automated Soxhlet (Soxtec), and sonication. ${ }^{2}$ These methods use between 70 and 300 $\mathrm{mL}$ of hazardous solvents such as methylene chloride and thus produce large amounts of secondary waste. Waste minimization and pollution prevention have not usually played a role in development of procedures for waste characterization, but new procedures are needed that address these concerns.

A promising technique in this regard is supercritical fluid extraction (SFE), which has been used in many studies for the extraction of organic compounds from environmental solid samples. $^{3-20}$ Carbon dioxide is particularly advantageous when used as the supercritical fluid since the extraction solvent can be vented directly to the atmosphere. Organic solvents are needed only in small quantities for collection of the extracted analytes or to modify the 
supercritical fluid. In many instances, modifiers are needed to increase the extraction efficiency of SFE for certain matrices or analytes, ${ }^{21.22}$ especially for extracting polar materials from solids and sediments that exhibit a wide variety of matrix effects. HEPA filters are made of glass fibers held together with a binder and should be much more uniform. They would not be expected to show the wide variety of matrix effects seen in soils and sediments so modification of the supercritical fluid should not be required.

The Analytical Chemistry Laboratory (ACL) at Argonne National Laboratory (ANL) is assisting the Waste Management Department of DOE's Environmental and Waste Management Programs in the characterization of historical HEPA filter waste to show that it meets the Hanford waste acceptance criteria. ${ }^{23}$ The ACL has been using sonication as the extraction method to remove SVOCs from the HEPA filters for analysis.

However, a method based on SFE has been developed for extraction of SVOCs from HEPA filters. The method was developed by working with spiked filter material. Results for the supercritical fluid extraction of 98 acid, base, and neutral SVOCs analyzed under the EPA's SW-846 Method 8270 are compared to extraction and analysis using the traditional extraction techniques. 


\section{EXPERIMENTAL}

A. $\underline{\text { Standards }}$

All SW-846 Method 8270 internal standards, base/neutral and acid surrogates, and the decafluorotriphenylphosphine (DFTPP) gas chromatography/mass spectrometry (GC/MS) tuning standard were purchased from ULTRA Scientific (North Kingstown, RI). The semivolatile base/neutral and acid analytes (BNAs) were also purchased from ULTRA Scientific as eight separate mixtures in methylene chloride. The mixtures were combined with the acid and base/neutral surrogates to give a spiking solution with a concentration of $167 \mu \mathrm{g} / \mathrm{mL}$ for each of the $92 \mathrm{BNAs}$ and the three base/neutral surrogates and $333 \mu \mathrm{g} / \mathrm{mL}$ for each of the three acid surrogates. Calibration solutions for GC/MS were made by preparing a separate stock standard solution from the eight BNA mixtures. The stock solution was diluted to the appropriate concentrations and combined with the internal standards and surrogates. Table 1 lists the 98 compounds in the spiking solution grouped into arbitrary compound classes based on functional groups.

\section{B. Solvents}

The organic solvents used in this study (methylene chloride, acetone, and hexane) were capillary GC/GC-MS grade solvents from Burdick \& Jackson. Soxhlet and sonication extractions were performed using methylene chloride. For Soxtec extraction either 1:1 hexane:acetone or methylene chloride was used. The solvents studied for use as SFE collection solvents were methylene chloride, 1:1 methylene chloride:acetone, and 1:1 hexane:acetone.

\section{HEPA Filter Spiking}

Sheets of HEPA filter material were obtained from Flanders Filters, Inc. (Washington, NC). The sheets were cut into small pieces approximately $1 \mathrm{~cm}^{2}$ in size. This material had not 
been tested with DOP and subsequent extraction of the material revealed no significant quantities of semivolatile target analytes.

For each sample, a $1.0 \mathrm{~g}$ quantity of HEPA filter material was placed in a 2-oz. $(\sim 60 \mathrm{~mL})$ glass bottle. A sample weight of $1.0 \mathrm{~g}$ was chosen to simulate the amount normally used in HEPA filter analysis at ANL. Next, $600 \mu \mathrm{L}$ of the methylene chloride spiking solution described above was added dropwise to the material. Thus, each sample was spiked with $100 \mu \mathrm{g}$ of each of the BNA analytes and base/neutral surrogate standards and $200 \mu \mathrm{g}$ of each of the acid surrogate standards. The solvent was allowed to evaporate, and the samples were sealed in the bottles and allowed to sit for approximately $1 \mathrm{~h}$. After the spiked filter material was transferred to the extraction apparatus, the bottles used for spiking were triple rinsed with methylene chloride, and the rinsate was concentrated and analyzed for semivolatile compounds. BNA concentrations found in the bottle rinsate were used to correct the total spike amounts.

\section{Extraction of Samples Using Supercritical Fluid Extraction}

All supercritical fluid extractions were carried out by using a Dionex SFE-703 instrument (Dionex Corporation, Sunnyvale, CA). Figure 1 shows a schematic diagram of the SFE extractor. Up to eight samples may be extracted at one time. The supercritical $\mathrm{CO}_{2}$ is depressurized through heated, wafer-style restrictors and bubbled through a vial of a collection solvent. The instrument was equipped with 10-mL stainless steel cells (hand-tight 14 x 60 -mm vessels from Keystone Scientific, Bellefonte, PA) and $250 \mathrm{~mL} / \mathrm{min}$ heated restrictors. The cells are capable of operating at up to $10,000 \mathrm{psi}\left(6.9 \times 10^{4} \mathrm{kPa}\right)$. The carbon dioxide used was SFC/SFE-grade $\mathrm{CO}_{2}$ with helium head space at $2000 \mathrm{psi}\left(1.38 \times 10^{4} \mathrm{kPa}\right)$ (Air Products and Chemicals, Lehigh Valley, PA). Although the system is capable of extracting up to eight samples simultaneously, in general, samples were extracted in duplicate. The spiked filter material was loaded into the 
SFE cells between layers of Ottawa sand standard (Fisher Scientific, Pittsburgh, PA). Unless otherwise noted, the extractions were carried out dynamically for $30 \mathrm{~min}$, the SFE restrictors were held at $150^{\circ} \mathrm{C}$, and the analytes were collected in $15 \mathrm{~mL}$ of methylene chloride held at $0^{\circ} \mathrm{C}$. After the extractions were complete, the collection solvent was concentrated to $1 \mathrm{~mL}$ by using a Kuderna-Danish (K-D) concentrator. The specifics of the optimization process and experimental conditions are given in Section III.

\section{E. Extraction of HEPA Filters Using Traditional Methods}

Soxhlet extraction of spiked HEPA filter samples was carried out using a standard extraction apparatus. First, $1.0 \mathrm{~g}$ of spiked filter material was placed in a Soxhlet thimble and covered with sand. Next, $300 \mathrm{~mL}$ of methylene chloride was added to the apparatus and the extraction was carried out for approximately $16 \mathrm{~h}$. The final extract was concentrated to $1 \mathrm{~mL}$ using a K-D concentrator. For this method, 12 extractions (three sets of four) were run over the course of several months.

Automated Soxhlet (Soxtec) extractions were carried out with a Tector Soxtec System HT2 extraction unit. Two sets of four samples were extracted, one set with $75 \mathrm{~mL}$ of methylene chloride, one with $75 \mathrm{~mL}$ of 1:1 hexane:acetone. The samples were extracted in the boiling solvent for $1 \mathrm{~h}$ followed by $1 \mathrm{~h}$ of rinsing with the sample suspended above the solvent. The extraction solvent was concentrated to approximately $10 \mathrm{~mL}$ in the Soxtec apparatus and then to $1 \mathrm{~mL}$ in a $\mathrm{K}-\mathrm{D}$ concentrator.

Sonication extraction followed an extraction procedure that was slightly modified from the one normally used at ANL for HEPA filters. First, $25 \mathrm{~mL}$ of methylene chloride was added to the $1.0 \mathrm{~g}$ of the spiked solid. The solution was sonicated for two minutes using a Heat Systems-Ultrasonics, Inc. Sonicator unit. The extraction solvent was decanted through a pipet 
filled with glass wool. After one sonication, it was obvious from the color of the filter material that not all of the semivolatiles had been removed. Therefore, the sonication was repeated twice more with fresh solvent. The standard procedure uses only one sonication step. The three resulting liquid extracts were combined and concentrated to $1 \mathrm{~mL}$ in a K-D concentrator. Six samples were extracted by using this process.

\section{F. Extract Analysis}

All SFE, sonication, Soxtec, and Soxhlet extracts were analyzed by GC/MS according to SW-846 Method 8270. ${ }^{2}$ The analyses were run on a Hewlett-Packard 5890 Series II gas chromatograph (equipped with a 5973A automatic liquid sampler) interfaced to a 5989A quadrupole mass spectrometer. A splitless injection of $1 \mu \mathrm{L}$ of sample was made onto a J\&W DB-5MS column (30-m length $\times 0.32-\mathrm{mm}$ i.d. $\times 0.25 \mu \mathrm{m}$ film thickness). Helium was used as the carrier gas, with an approximate flow of $1.5 \mathrm{~mL} / \mathrm{min}$ through the column and a split flow of $50 \mathrm{~mL} / \mathrm{min}$. The injector purge valve was opened 45 seconds after injection. The injector temperature was held at $280^{\circ} \mathrm{C}$. The initial oven temperature of $35^{\circ} \mathrm{C}$ was held for $2 \mathrm{~min}$, ramped to $200^{\circ} \mathrm{C}$ at $6^{\circ} \mathrm{C} / \mathrm{min}$, ramped to $280^{\circ} \mathrm{C}$ at $10^{\circ} \mathrm{C} / \mathrm{min}$, and held at $280^{\circ} \mathrm{C}$ for $17.5 \mathrm{~min}$. The GC/MS interface temperature was held at $280^{\circ} \mathrm{C}$ with an ion source temperature of $270^{\circ} \mathrm{C}$. Compounds were ionized by using $70 \mathrm{eV}$ electron impact ionization, and spectral scan data were taken over a mass range of $35-500 \mathrm{amu}$. 


\section{RESULTS AND DISCUSSION}

\section{A. Control Tests and Supercritical Fluid Extraction Method Development}

To determine any possible contamination of the sand and HEPA filter material, 10-mL cells full of the Ottawa sand standard or $1.0 \mathrm{~g}$ blank HEPA filter material (plus sand to fill the cell) were subjected to a 30-min dynamic extraction with supercritical $\mathrm{CO}_{2}$. Any extracted material was collected in methylene chloride and run through the normal concentration process and GC/MS analysis. Extraction of sand showed no semivolatile organic compounds. Extraction of the HEPA filter material gave very small amounts of three phthalates $(<2 \mu \mathrm{g})$ and several polynuclear aromatic hydrocarbons (PAHs) $(<0.5 \mu \mathrm{g})$. Compared to the spike amounts and the errors associated with the extraction and analysis, these values are not significant.

Several extractions were run on blank sand with the semivolatiles spiked into the collection solvent. This allows the determination of possible volatilization losses resulting from bubbling the $\mathrm{CO}_{2}$ through the solvent. In four determinations, the average recovery for all 98 spike compounds was greater than $95 \%$.

To determine the effect of the collection solvent on recovery, sand was spiked with the semivolatile compounds and extracted by using three different solvents and two different solvent volumes. The three solvents are standard solvents used for semivolatile organic extraction: 1:1 hexane:acetone; 1:1 methylene chloride:acetone; and methylene chloride. Six extractions were done using each solvent; four with $15 \mathrm{~mL}$ of solvent and two with $10 \mathrm{~mL}$. Figure 2 compares the recoveries for the three solvents $(15 \mathrm{~mL})$ by compound class, and Table 2 gives the average recoveries for the 98 compounds by solvent and volume. Average recoveries for individual compounds and compound classes show somewhat larger variation, but, overall, there is little difference between the three solvents and the two solvent volumes used (the maximum difference 
is about 5\%). Methylene chloride was chosen for most of the experimental work. It requires no solvent mixing and does not have the drawbacks of the acetone-containing solvents, which always show large acetone aldol condensation product peaks in the GC/MS analysis.

To optimize the extraction of semivolatile organic compounds from HEPA filter material, extractions were carried out at temperatures of $40,50,75,100$ and $125^{\circ} \mathrm{C}$ and pressures of 300 , 400,500 , and 600 atm $(30.4,40.5,50.7$, and $60.8 \mathrm{MPa})$. Representative data for average recoveries (by compound class) are shown in Figs. 3 and 4. Figure 3 shows the recovery variation with supercritical fluid pressure at an extraction temperature of $50^{\circ} \mathrm{C}$. The compound recoveries rise between 300 and 400 atm (30.4 and $40.5 \mathrm{MPa}$ ) and then drop off as the pressure is increased further. Figure 4 shows the temperature dependence of the semivolatile recoveries at an extraction pressure of $400 \mathrm{~atm}(40.5 \mathrm{MPa})$. The recoveries rise between 40 and $50^{\circ} \mathrm{C}$ and then decrease as the temperature increases. Overall, the highest recoveries were obtained at $50^{\circ} \mathrm{C}$ and $400 \mathrm{~atm}(40.5 \mathrm{MPa})$.

Duplicate extractions were made with dynamic extraction times of $5,10,20,30,45$, and $60 \mathrm{~min}$. The extraction temperature and pressure were held at $50^{\circ} \mathrm{C}$ and $400 \mathrm{~atm}(40.5 \mathrm{MPa})$. Figure 5 shows the variation of the average percent recovery across all 98 compounds versus the extraction time. The recovery increases rapidly at short extraction times and then levels off. The figure shows that extraction is essentially complete after about $30 \mathrm{~min}$.

Final SFE extraction data were obtained by running three sets of eight spiked samples over the course of several weeks. The method differed slightly for each set of samples. Two sets were extracted for $45 \mathrm{~min}$, one using hexane/acetone collection solvent and one using methylene chloride. The third set was extracted for $30 \mathrm{~min}$ using methylene chloride. Table 3 presents a comparison of the average results for each of the 98 semivolatile organic compounds 
for the three sets of data. In general, differences seen among the three sets of data are no larger than what is normally expected in semivolatile extraction and analysis. The only major difference appears to be the lower recoveries of aromatic amines when hexane/acetone is used compared to when methylene chloride is used. Average percent recoveries across all 98 compounds are $70.1 \%$ (hexane/acetone, 45 minutes), $71.0 \%$ (methylene chloride, 30 minutes), and $67.4 \%$ (methylene chloride, 45 minutes).

\section{B. Comparison of Results from Supercritical Fluid Extraction and Traditional Extraction $\underline{\text { Methods }}$}

Table 4 compares the SFE recoveries with those from Soxhlet, Soxtec, and sonication. The SFE results are the average of the 24 final extractions just discussed. The Soxhlet numbers are the average of 12 extractions (three sets of four) run over the course of several months. Soxtec recoveries are the average of two sets of four samples, one set extracted with hexane/acetone and one with methylene chloride. Sonication results are from extraction of a set of six spiked samples. The lower percent relative standard deviation (\%RSD) values for sonication are due in part to the fact that all six samples were processed as a group, while the other techniques involved running several groups of samples over an extended period of time.

Sonication and SFE are compared in Figures 6-12. Figures 6-11 plot average percent recovery for each compound. The error bars indicate plus and minus one standard deviation from the mean. Figure 12 gives average percent recovery values by compound class. Overall, for the 98 compounds, the average recovery for sonication is $74.0 \%$ and for SFE, $70.2 \%$. For 58 compounds, average recoveries are higher for sonication, while the remaining 40 compounds have higher values with SFE. In general, there is good agreement between the sonication and SFE results for many of the compound classes. Excellent agreement is seen with the phenols, except for 4-nitrophenol and 2,4-dinitrophenol, where the sonication recoveries are higher. Some 
differences are observed with the polynuclear aromatic hydrocarbons (PAHs). Agreement is seen with many of the smaller PAHs (except 2-methylnaphthalene), but SFE appears to be more efficient for many of the larger PAHs, especially chrysene, 7,12-dimethylbenz(a)anthracene, and 3-methylcholanthrene. Other compounds with larger discrepancies (higher sonication yields) include $\alpha, \alpha$-dimethylphenethylamine, 4-chloroaniline, 4-aminobiphenyl, benzidine, and dibenz $(a, j)$ acridine. Sonication is the method used at ANL for extraction of HEPA filters. However, SFE gives comparable extraction yields and would require less extraction solvent and produce less waste. In the current experiments, $75 \mathrm{~mL}$ of methylene chloride was used in the sonication extraction but only $15 \mathrm{~mL}$ for SFE. The ANL sonication method for extraction of waste HEPA filters generally uses $25 \mathrm{~mL}$ of solvent for a 1-g sample. There is thus a small reduction in solvent usage. In SFE, the analyte/collection solvent mixture is physically separated from the sample during extraction; thus, no filtration or sample rinsing is necessary following the extraction step.

A comparison of Soxhlet and SFE results is given in Figs. 13-18 for individual compounds and Fig. 19 for compound classes. Average recoveries for the two techniques are $82.7 \%$ and $70.2 \%$, respectively. This difference is borne out by the data for the individual compounds. The average recovery for 88 out of the 98 compounds is higher with Soxhlet extraction. As mentioned above, SFE tends to be fairly efficient at extracting the higher molecular weight PAHs. In five of the 10 cases in which SFE yields are higher, the analyte is a PAH.

Soxhlet extraction is obviously more efficient at extracting semivolatile organic compounds from HEPA filters than SFE with unmodified $\mathrm{CO}_{2}$. However, SFE reduces the extraction time by a factor of about $20-30(30-45 \mathrm{~min}$ versus $16 \mathrm{~h})$ and the extraction solvent 
volume by a factor of $20-30(10-15 \mathrm{~mL}$ versus $300 \mathrm{~mL})$; these efficiencies would significantly reduce sample analysis costs.

Figures 20-25 compare the Soxtec and SFE recoveries for all 98 semivolatile compounds. Figure 26 compares the average recovery values for the compound classes. Average recoveries for SFE are higher for 87 out of the 98 compounds. The average recovery for all compounds is $62.9 \%$ for Soxtec and $70.2 \%$ for SFE. The only two compounds where Soxtec yields significantly higher recoveries are di-n-butylphthalate and bis(2-ethylhexyl)phthalate. It is quite likely that this is due to extract contamination rather than an increase in extraction efficiency. Significant differences are especially evident with the PAHs, starting with pyrene and continuing through the higher molecular weight species.

In addition to providing higher extraction yields, SFE also uses less solvent than automated Soxhlet extractions. The Soxtec extractions reported here used a total of $75 \mathrm{~mL}$ of solvent, five times more than SFE. Another advantage is that SFE is also faster. The extraction itself is $30-45 \mathrm{~min}$ versus $2 \mathrm{~h}$ for Soxtec, which also requires additional time to evaporate the excess solvent. 


\section{CONCLUSIONS}

The extraction of SW-846 Method 8270 acid, base, and neutral semivolatile organic compounds spiked onto blank HEPA filter material has been carried out using supercritical fluid extraction with unmodified $\mathrm{CO}_{2}$. Optimum conditions have been determined for extraction with a Dionex SFE-703 instrument: the extraction is carried out at a temperature of $50^{\circ} \mathrm{C}$ and a pressure of $400 \mathrm{~atm}(40.5 \mathrm{MPa})$. The instrument has $250 \mathrm{~mL} / \mathrm{min}$ restrictors that are held at a temperature of $150^{\circ} \mathrm{C}$. The extraction is carried out dynamically for $30-45 \mathrm{~min}$. The extracted compounds are collected by bubbling the $\mathrm{CO}_{2}$ through $10-15 \mathrm{~mL}$ of collection solvent (methylene chloride, 1:1 hexane/acetone, and 1:1 methylene chloride/acetone all work equally well) held at $0^{\circ} \mathrm{C}$.

Supercritical fluid extraction of the semivolatile organics has been compared to the conventional extraction techniques of Soxhlet, automated Soxhlet (Soxtec), and sonication. The SFE technique is seen to give higher extraction yields than Soxtec and is comparable to sonication. Soxhlet extraction gives the highest recoveries of all of the techniques. Average recoveries for the 98 semivolatile compounds are $82.7 \%$ for Soxhlet, $74.0 \%$ for sonication, $70.2 \%$ for SFE, and $62.9 \%$ for Soxtec.

The SFE approach reduces the volume of hazardous solvents used and thus the amount of waste produced. In the current study, $75 \mathrm{~mL}$ of solvent was necessary for both sonication and Soxtec extraction, while $300 \mathrm{~mL}$ of solvent was used for the Soxhlet extractions. If $15 \mathrm{~mL}$ of solvent is used for analyte collection, SFE reduces the solvent usage by a factor of between 5 and 20. This factor can be increased if the amount of solvent is reduced to $10 \mathrm{~mL}$.

In terms of extraction times, SFE has a clear advantage over Soxhlet (30-45 min versus 16-18 $\mathrm{h}$ ). It is also faster than Soxtec, which requires $2 \mathrm{~h}$ for the extraction. Sonication sample 
extraction times are fairly comparable if only one extraction is done at a time. Because the instrument used here can perform eight extractions at a time, SFE would be more efficient than sonication. 


\section{ACKNOWLEDGMENTS}

The author wishes to thank Yifen Tsai for her contribution to this work. Thanks also go to Jimmy Harris of Flanders Filters, Inc., who supplied the blank HEPA filter material. This work was performed for the U. S. Department of Energy, Office of Pollution Prevention (EM-77) under Contract W-31-109-Eng-38.

\section{REFERENCES}

1. K. A. Gablin, Solutions for Dioctyl Phthalate (DOP) Tested High Efficiency Particulate Air (HEPA) Filters Destined for Disposal at Hanford, Washington, Argonne National Laboratory Report ANL/EWM/CP--78035 (Nov. 1992).

2. Test Methods for Evaluating Solid Waste, U.S. Environmental Protection Agency, Document SW-846, 3rd ed., Office of Solid Waste and Emergency Response, Washington, DC (Sept. 1994).

3. V. Lopez-Avila and N. S. Dodhiwala, Method for the Supercritical Fluid Extraction of Soils/Sediments, U.S. Environmental Protection Agency Report EPA/600/4-90/026, Washington, DC (1990).

4. V. Lopez-Avila, W. F. Beckert, and S. Billets, "Supercritical Fluid Extraction and Its Application to Environmental Analysis," Waste Testing and Quality Assurance: Third Volume, ASTM STP 1075, D. Friedman, Ed., American Society for Testing and Materials, Philadelphia, PA (1991).

5. H. Engelhardt, J. Zapp, and P. Kolla, "Sample Preparation by Supercritical Fluid Extraction in Environmental, Food, and Polymer Analysis," Chromatographia 32, 527-537, (1991).

6. V. Lopez-Avila and W. F. Beckert, "Supercritical Fluid Extraction in Environmental Analysis," Supercritical Fluid Technology: Theoretical and Applied Approaches to Analytical Chemistry, F. V. Bright and M. E. P. McNally, Eds., ACS Symposium Series 488, American Chemical Society, Washington, DC (1992).

7. L. J. D. Myer, J. H. Damian, P. B. Liescheski, and J. Tehrani, "Supercritical Fluid Extraction versus Soxhlet Sample Preparation: A Comparative Study for Extraction and Analysis of Organics in Solid Matrices," Supercritical Fluid Technology: Theoretical and Applied Approaches to Analytical Chemistry, F. V. Bright and M. E. P. McNally, Eds., ACS Symposium Series 488, American Chemical Society, Washington, DC (1992). 
8. S. B. Hawthorne, D. J. Miller, J. J. Langenfeld, and M. D. Burford, "Analytical-Scale Extraction of Environmental Samples Using Supercritical Fluids," Pollution Prevention in Industrial Processes: The Role of Process Analytical Chemistry, J. J. Breen and M. J. Dellarco, Eds., ACS Symposium Series 508, American Chemical Society, Washington, DC (1992).

9. T. S. Oostdyk, R. L. Grob, J. L. Snyder, and M. E. McNally, "Study of Sonication and Supercritical Fluid Extraction of Primary Aromatic Amines," Anal. Chem. $\underline{65}$, 596-600, (1993).

10. M. D. Burford, S. B. Hawthorne, and D. J. Miller, "Extraction Rates of Spiked versus Native PAHs from Heterogeneous Environmental Samples Using Supercritical Fluid Extraction and Sonication in Methylene Chloride," Anal. Chem. 65, 1497-1505, (1993).

11. V. Camel, A. Tambuté, and M. Caude, "Analytical-Scale Supercritical Fluid Extraction: A Promising Technique for the Determination of Pollutants in Environmental Matrices," J. Chromatogr. 642, 263-281, (1993).

12. V. Janda, K. D. Bartle, and A. A. Clifford, "Supercritical Fluid Extraction in Environmental Analysis," J. Chromatogr. 642, 283-299, (1993).

13. S. B. Hawthorne, D. J. Miller, M. D. Burford, J. J. Langenfeld, S. Eckert-Tilotta, and P. K. Louie, "Factors Controlling Quantitative Supercritical Fluid Extraction of Environmental Samples," J. Chromatogr. 642, 301-317, (1993).

14. M. I. L. Bicking, T. G. Hayes, J. C. Kiley, and S. N. Deming, "An Experimental Design Approach to the Optimization of Supercritical Fluid Extraction for the Determination of Oil and Grease in Soil," J. Chromatogr. Sci. 31, 170-176, (1993).

15. T. S. Oostdyk, R. L. Grob, J. L. Snyder, and M. E. McNally, "Optimization of the Supercritical Fluid Extraction of Primary Aromatic Amines," J. Chromatogr. Sci. $\underline{31}$, 177182, (1993).

16. D. R. Gere, C. R. Knipe, P. Castelli, J. Hedrick, L. G. Randall Frank, H. SchulenbergSchell, R. Schuster, L. Doherty, J. Orolin, and H. B. Lee, "Bridging the Automation Gap between Sample Preparation and Analysis: An Overview of SFE, GC-MS, and HPLC Applied to Environmental Samples," J. Chromatogr. Sci. 1ㅣ, 246-258, (1993).

17. T. L. Chester, J. D. Pinkston, and D. E. Raynie, "Supercritical Fluid Chromatography and Extraction," Anal. Chem. 66, 106R-130R, (1994).

18. S. Reindl and F. Höfler, "Optimization of the Parameters in Supercritical Fluid Extraction of Polynuclear Aromatic Hydrocarbons from Soil Samples," Anal. Chem. 66, 1808-1816, (1994). 
19. S. B. Hawthorne, Y. Yang, and D. J. Miller, "Extraction of Organic Pollutants from Environmental Solids with Sub- and Supercritical Water," Anal. Chem. 66, 2912-2920, (1994).

20. S. B. Hawthorne and D. J. Miller, "Direct Comparison of Soxhlet and Low- and HighTemperature Supercritical $\mathrm{CO}_{2}$ Extraction Efficiencies of Organics from Environmental Solids," Anal. Chem. 66, 4005-4012, (1994).

21. J. J. Langenfeld, S. B. Hawthorne, D. J. Miller, and J. Pawliszyn, "Role of Modifiers for Analytical-Scale Supercritical Fluid Extraction of Environmental Samples," Anal. Chem. 66, 909-916, (1994).

22. Y. Yang, A. Gharaibeh, S. B. Hawthorne, and D. J. Miller, "Combined Temperature/Modifier Effects on Supercritical $\mathrm{CO}_{2}$ Extraction Efficiencies of Polycyclic Aromatic Hydrocarbons from Environmental Samples," Anal. Chem. 67, 641-646, (1995).

23. A. M. Essling, L. E. Ross, F. P. Smith, I. M. Fox, E. A. Huff, D. R. Huff, P. Melnikov, S. D. Kent, K. J. Parish, Y. Tsai, L. L. Chromizky, P. D. Postlethwait, E. Vinokour, L. B. TenKate, T. TenKate, J. S. Yaeger, L. L. Smith, F. Markun, D. L. Bowers, A. S. Boparai, and D. G. Graczyk, "Characterization of Used HEPA Filters for Disposal," Analytical Chemistry Laboratory Progress Report for FY 1994, Argonne National Laboratory Report ANL/ACL-94/4 (Dec. 1994). 
Table 1. RCRA Method 8270 Base/Neutral/Acid Analytes Used in This Study

\begin{tabular}{||l|l||}
\hline \multicolumn{2}{|c|}{ Alkylphenols } \\
\hline Phenol & 4-Methylphenol \\
\hline Phenol-d $_{5}{ }^{2}$ & 2,4-Dimethylphenol \\
\hline 2-Methylphenol & \\
\hline & Halophenols \\
\hline 2-Fluorophenol ${ }^{\mathrm{a}}$ & 2,4,5-Trichlorophenol \\
\hline 2-Chlorophenol & 2,4,6-Trichlorophenol \\
\hline 4-Chloro-3-methylphenol & 2,3,4,6-Tetrachlorophenol \\
\hline 2,4-Dichlorophenol & Pentachlorophenol \\
\hline 2,6-Dichlorophenol & 2,4,6-Tribromophenol \\
\hline & Nitrophenols \\
\hline 2-Nitrophenol & 2,4-Dinitrophenol \\
\hline 4-Nitrophenol & 4,6-Dinitro-2-methylphenol \\
\hline \multicolumn{2}{|c||}{} \\
\hline Benzoic acid & Carboxylic acid \\
\hline \multicolumn{2}{|c|}{ Ethers } \\
\hline Benzyl alcohol & Dibenzofuran \\
\hline bis(2-Chloroisopropyl)ether & 4-Chlorophenyl phenyl ether \\
\hline bis(2-Chloroethoxy)methane & 4-Bromophenyl phenyl ether \\
\hline & Sulfonates \\
\hline Methyl methanesulfonate & Ethyl methanesulfonate \\
\hline
\end{tabular}


Table 1 (contd)

\begin{tabular}{|c|c|}
\hline \multicolumn{2}{|c|}{ PAHs } \\
\hline Acenaphthene & 7,12-Dimethylbenz(a)anthracene \\
\hline Acenaphthylene & Fluoranthene \\
\hline Anthracene & Fluorene \\
\hline Benzo(a)anthracene & Indeno(1,2,3-cd)pyrene \\
\hline Benzo(b)fluoranthene & 3-Methylcholanthrene \\
\hline Benzo(k)fluoranthene & 2-Methylnaphthalene \\
\hline Benzo(g,h,i)perylene & Naphthalene \\
\hline Benzo(a)pyrene & Phenanthrene \\
\hline Chrysene & Pyrene \\
\hline Dibenzo(a,h)anthracene & Terphenyl- $\mathrm{d}_{14}{ }^{\mathrm{a}}$ \\
\hline \multicolumn{2}{|c|}{ Phthalates } \\
\hline Dimethylphthalate & Butylbenzylphthalate \\
\hline Diethylphthalate & bis(2-Ethylhexyl)phthalate \\
\hline Di-n-butylphthalate & Di-n-octylphthalate \\
\hline \multicolumn{2}{|c|}{ Halocarbons } \\
\hline 2-Fluorobiphenyl ${ }^{a}$ & 1,2,4,5-Tetrachlorobenzene \\
\hline 1-Chloronaphthalene & Pentachlorobenzene \\
\hline 2-Chloronaphthalene & Hexachlorobenzene \\
\hline 1,2-Dichlorobenzene & Hexachloroethane \\
\hline 1,3-Dichlorobenzene & Hexachlorobutadiene \\
\hline 1,4-Dichlorobenzene & Hexachlorocyclopentadiene \\
\hline \multicolumn{2}{|l|}{ 1,2,4-Trichlorobenzene } \\
\hline \multicolumn{2}{|c|}{ Amides } \\
\hline Phenacetin & Pronamide \\
\hline \multicolumn{2}{|c|}{ Pyridines } \\
\hline 2-Picoline & Dibenz $(\mathrm{a}, \mathrm{j})$ acridine \\
\hline
\end{tabular}


Table 1 (contd)

\begin{tabular}{||l|l||}
\hline \multicolumn{2}{|c||}{ Aromatic Amines } \\
\hline 4-Aminobiphenyl & Diphenylamine \\
\hline Aniline & 1-Naphthylamine \\
\hline Benzidine & 2-Naphthylamine \\
\hline 4-Chloroaniline & 2-Nitroaniline \\
\hline 3,3'-Dichlorobenzidine & 3-Nitroaniline \\
\hline$\alpha, \alpha$-Dimethylphenethylamine & 4-Nitroaniline \\
\hline & Nitrosamines \\
\hline N-Nitrosodimethylamine & N-Nitrosodiphenylamine \\
\hline N-Nitrosodi-n-propylamine & N-Nitrosopiperidine \\
\hline N-Nitrosodi-n-butylamine & \\
\hline \multicolumn{2}{|c||}{ Hydrazine } \\
\hline $1,2-$ Diphenylhydrazine & \\
\hline \multicolumn{2}{|c||}{ Azoamine } \\
\hline p-Dimethylaminoazobenzene & \\
\hline & Nitrobenzenes \\
\hline Nitrobenzene & 2,6-Dinitrotoluene \\
\hline Nitrobenzene- ${ }_{5}{ }^{2}$ & Pentachloronitrobenzene \\
\hline 2,4-Dinitrotoluene & \\
\hline \hline
\end{tabular}

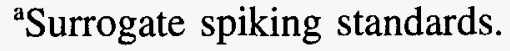


Table 2. Average Semivolatile Recoveries versus

Collection Solvent and Solvent Volume for SFE of Spiked Sand

\begin{tabular}{||l|c|c|}
\hline \multirow{2}{*}{ Solvent } & \multicolumn{2}{|c|}{ Average Percent Recovery } \\
\cline { 2 - 3 } & $10 \mathrm{~mL}$ Solvent & $15 \mathrm{~mL}$ Solvent \\
\hline \hline $1: 1$ Hexane:acetone & 64.7 & 64.8 \\
\hline 1:1 Methylene chloride:acetone & 59.6 & 62.6 \\
\hline Methylene chloride & 63.4 & 63.0 \\
\hline
\end{tabular}


Table 3. Comparison of Average SFE Recoveries for 30- and 45-min Extractions with Methylene Chloride and Hexane/Acetone Extraction Solvents




Table 3 (contd)

\begin{tabular}{|c|c|c|c|c|c|c|}
\hline \multirow{2}{*}{ Compound } & \multicolumn{2}{|c|}{$45 \mathrm{~min}, \mathrm{Hex} / \mathrm{Ace}^{\mathrm{a}}$} & \multicolumn{2}{|c|}{$30 \mathrm{~min}, \mathrm{MC}^{\mathrm{b}}$} & \multicolumn{2}{|c|}{$45 \mathrm{~min}, \mathrm{MC}^{\mathrm{b}}$} \\
\hline & $\%$ Recovery & $\% \mathrm{RSD}^{\mathrm{c}}$ & $\%$ Recovery & $\% \operatorname{RSD}^{c}$ & \% Recovery & $\% \mathrm{RSD}^{\mathrm{c}}$ \\
\hline \multicolumn{7}{|l|}{ Nitrophenols } \\
\hline 2-Nitrophenol & 65 & 8 & 68 & 14 & 58 & 25 \\
\hline 2,4-Dinitrophenol & 70 & 6 & 109 & 17 & 112 & 18 \\
\hline \multicolumn{7}{|l|}{ Phthalates } \\
\hline Dimethylphthalate & 81 & 5 & 84 & 7 & 81 & 10 \\
\hline Diethylphthalate & 83 & 4 & 82 & 12 & 81 & 7 \\
\hline Di-n-octylphthalate & 103 & 6 & 89 & 13 & 89 & 8 \\
\hline \multicolumn{7}{|l|}{ Ketones } \\
\hline Acetophenone & 62 & 4 & 57 & 18 & 49 & 28 \\
\hline Isophorone & 73 & 5 & 67 & 10 & 61 & 19 \\
\hline \multicolumn{7}{|l|}{ Sulfonates } \\
\hline Methyl methanesulfonate & 47 & 5 & 47 & 21 & 36 & 39 \\
\hline Ethyl methanesulfonate & 60 & 5 & 52 & 17 & 45 & 30 \\
\hline
\end{tabular}


Table 3 (contd)

\begin{tabular}{|c|c|c|c|c|c|c|}
\hline \multirow{2}{*}{ Compound } & \multicolumn{2}{|c|}{$45 \mathrm{~min}, \mathrm{Hex} / \mathrm{Ace}^{\mathrm{a}}$} & \multicolumn{2}{|c|}{$30 \mathrm{~min}, \mathrm{MC}^{\mathrm{b}}$} & \multicolumn{2}{|c|}{$45 \mathrm{~min}, \mathrm{MC}^{\mathrm{b}}$} \\
\hline & $\%$ Recovery & $\% \mathrm{RSD}^{\mathrm{c}}$ & \% Recovery & $\% \mathrm{RSD}^{\mathrm{c}}$ & $\%$ Recovery & $\% \mathrm{RSD}^{\mathrm{c}}$ \\
\hline PAHs & & & & & & \\
\hline Naphthalene & 70 & 5 & 61 & 14 & 54 & 26 \\
\hline 2-Methylnaphthalene & 73 & 4 & 69 & 11 & 62 & 17 \\
\hline Acenaphthylene & 80 & 5 & 75 & 9 & 77 & 7 \\
\hline Acenaphthene & 79 & 5 & 78 & 8 & 77 & 7 \\
\hline Fluorene & 72 & 4 & 82 & 8 & 79 & 8 \\
\hline Phenanthrene & 82 & 4 & 82 & 11 & 85 & 4 \\
\hline Anthracene & 81 & 3 & 81 & 10 & 82 & 7 \\
\hline Fluoranthene & 85 & 3 & 87 & 10 & 85 & 8 \\
\hline Pyrene & 94 & 5 & 85 & 12 & 82 & 5 \\
\hline Terphenyl- $\mathrm{d}_{14}$ & 93 & 4 & 89 & 9 & 88 & 8 \\
\hline Benzo(a)anthracene & 91 & 2 & 93 & 7 & 92 & 3 \\
\hline Chrysene & 91 & 2 & 89 & 10 & 92 & 3 \\
\hline Benzo(b)fluoranthene & 93 & 3 & 96 & 14 & 97 & 15 \\
\hline 7,12-Dimethylbenz(a)anthracene & 87 & 3 & 100 & 23 & 97 & 26 \\
\hline Benzo(k)fluoranthene & 90 & 3 & 95 & 8 & 95 & 7 \\
\hline Benzo(a)pyrene & 90 & 2 & 96 & 11 & 96 & 10 \\
\hline 3-Methylcholanthrene & 79 & 3 & 92 & 12 & 90 & 5 \\
\hline
\end{tabular}


Table 3 (contd)

\begin{tabular}{|c|c|c|c|c|c|c|}
\hline Compound & \multicolumn{2}{|c|}{$45 \mathrm{~min}, \mathrm{Hex} / \mathrm{Ace}^{\mathrm{a}}$} & \multicolumn{2}{|c|}{$30 \mathrm{~min}, \mathrm{MC}^{\mathrm{b}}$} & \multicolumn{2}{|c|}{$45 \mathrm{~min}, \mathrm{MC}^{\mathrm{b}}$} \\
\hline \multicolumn{7}{|l|}{ PAHs (contd) } \\
\hline Indeno(1,2,3-cd)pyrene & 96 & 3 & 94 & 18 & 91 & 13 \\
\hline Dibenzo(a,h)anthracene & 95 & 3 & 95 & 16 & 91 & 10 \\
\hline 1,3-Dichlorobenzene & 26 & 20 & 26 & 65 & 15 & 75 \\
\hline 1,4-Dichlorobenzene & 30 & 18 & 29 & 58 & 17 & 71 \\
\hline 1,2-Dichlorobenzene & 37 & 14 & 34 & 48 & 22 & 63 \\
\hline 1,2,4,5-Tetrachlorobenzene & 38 & 11 & 57 & 21 & 40 & 31 \\
\hline Hexachlorocyclopentadiene & 69 & 4 & 79 & 14 & 68 & 17 \\
\hline 2-Fluorobiphenyl & 80 & 5 & 71 & 11 & 78 & 11 \\
\hline 2-Chloronaphthalene & 77 & 7 & 79 & 19 & 70 & 12 \\
\hline 1-Chloronaphthalene & 78 & 6 & 68 & 8 & 75 & 14 \\
\hline Pentachlorobenzene & 70 & 4 & 87 & 11 & 81 & 6 \\
\hline Hexachlorobenzene & 73 & 3 & 85 & 4 & 88 & 6 \\
\hline
\end{tabular}


Table 3 (contd)

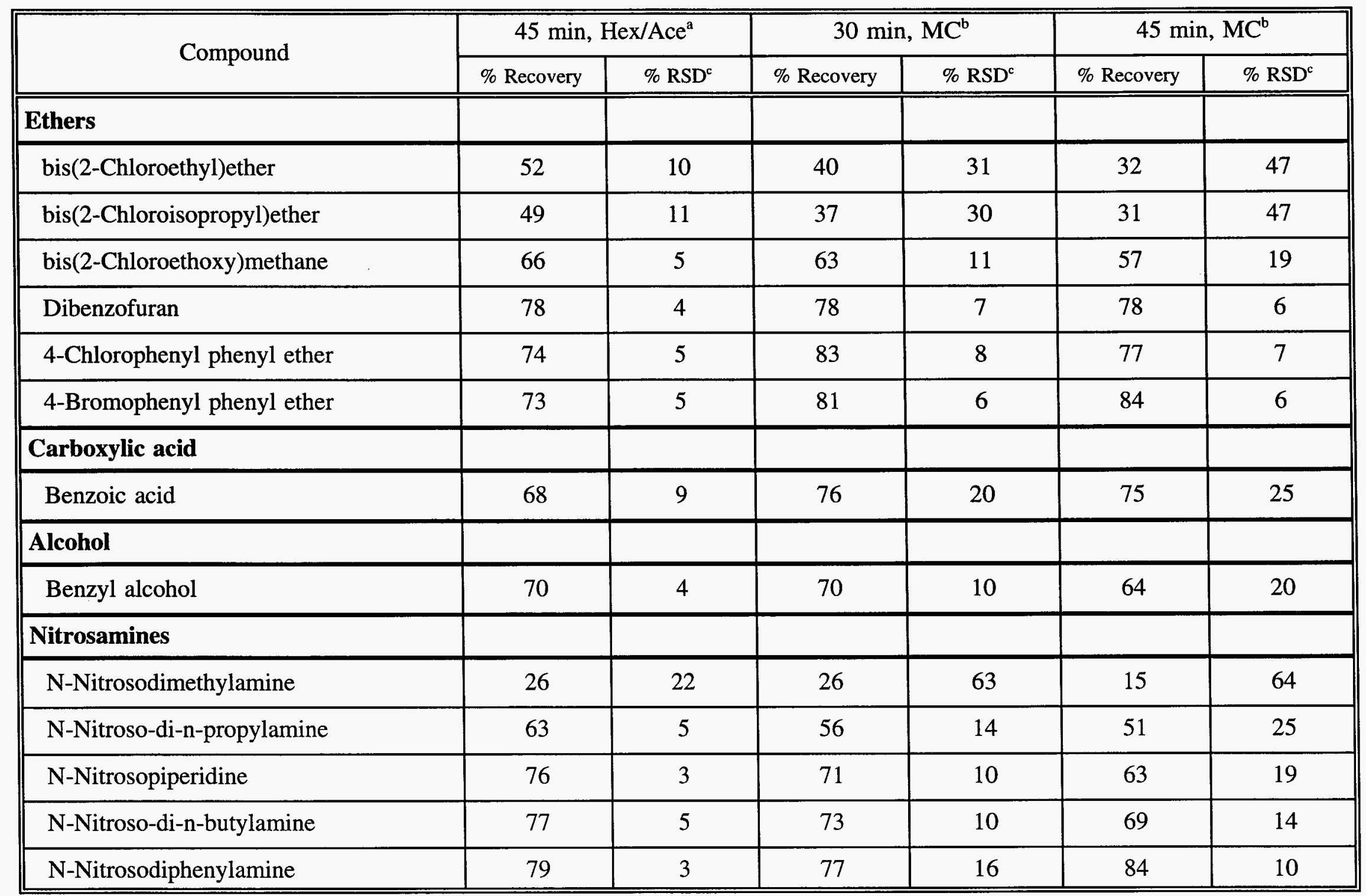


Table 3 (contd)

\begin{tabular}{|c|c|c|c|c|c|c|}
\hline Compound & \multicolumn{2}{|c|}{$45 \mathrm{~min}, \mathrm{Hex} / \mathrm{Ace}^{\mathrm{a}}$} & \multicolumn{2}{|c|}{$30 \mathrm{~min}, \mathrm{MC}^{\mathrm{b}}$} & \multicolumn{2}{|c|}{$45 \mathrm{~min}, \mathrm{MC}^{\mathrm{b}}$} \\
\hline \multicolumn{7}{|l|}{ Aromatic amines } \\
\hline Aniline & 45 & 6 & 53 & 17 & 46 & 32 \\
\hline$\alpha, \alpha$-Dimethylphenethylamine & 35 & 21 & 26 & 37 & 35 & 24 \\
\hline 3-Nitroaniline & 63 & 4 & 89 & 9 & 87 & 8 \\
\hline 2-Naphthylamine & 44 & 5 & 77 & 5 & 78 & 8 \\
\hline 1-Naphthylamine & 42 & 6 & 84 & 7 & 94 & 6 \\
\hline Benzidine & 20 & 28 & 54 & 20 & 67 & 24 \\
\hline 3,3'-Dichlorobenzidine & 41 & 10 & 89 & 4 & 91 & 2 \\
\hline \multicolumn{7}{|l|}{ Azoamine } \\
\hline p-Dimethylaminoazobenzene & 95 & 3 & 86 & 11 & 84 & 6 \\
\hline \multicolumn{7}{|l|}{ Amides } \\
\hline Phenacetin & 88 & 2 & 78 & 18 & 87 & 10 \\
\hline Pronamide & 80 & 4 & 82 & 14 & 86 & 9 \\
\hline
\end{tabular}


Table 3 (contd)

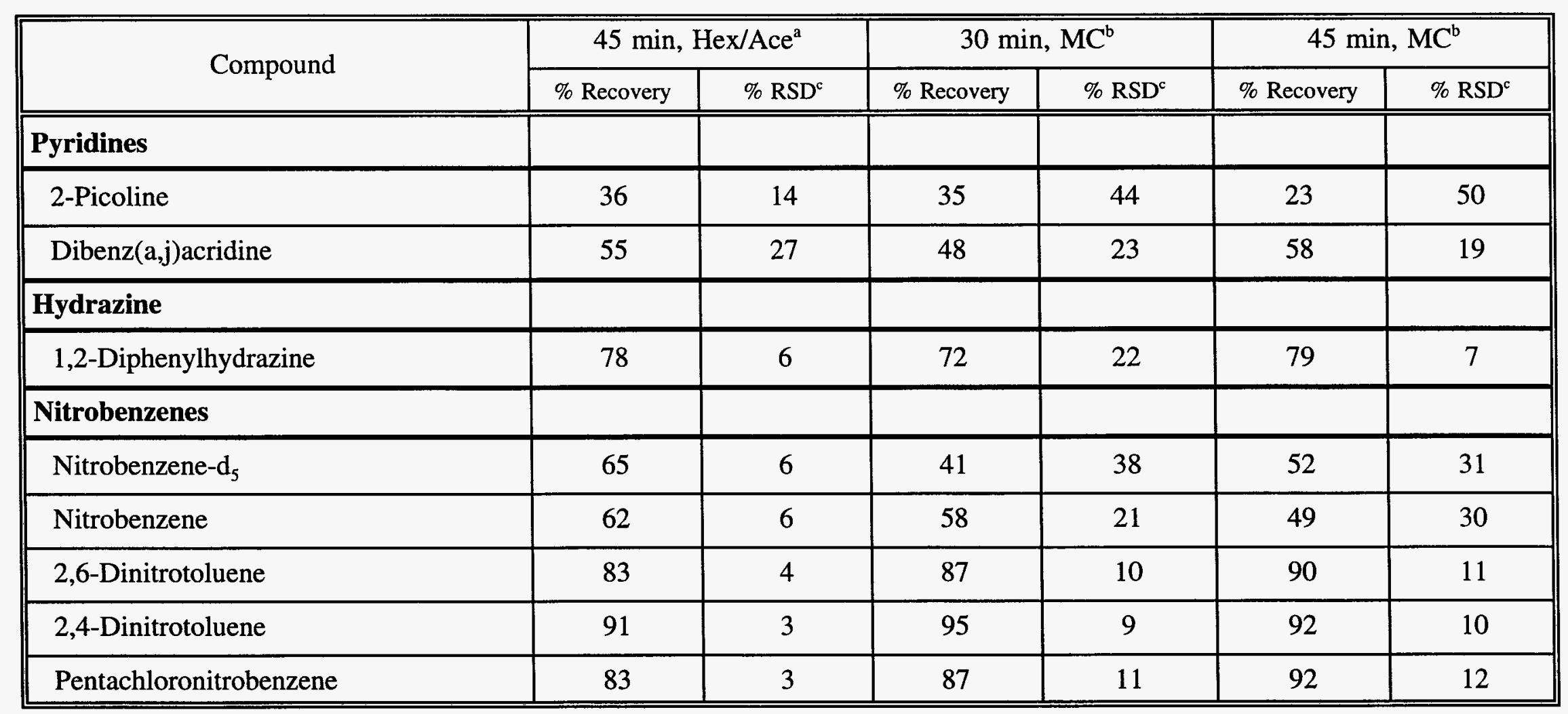

${ }^{a} \mathrm{Hex} /$ Ace $=1: 1$ hexane/acetone.

${ }^{b} \mathrm{MC}=$ methylene chloride.

${ }^{\mathrm{c}} \mathrm{RSD}=$ relative standard deviation 
Table 4. Comparison of Compound Recoveries between SFE and Traditional Extraction Techniques

\begin{tabular}{|c|c|c|c|c|c|c|c|c|}
\hline \multirow{2}{*}{ Compound } & \multicolumn{2}{|c|}{ SFFE } & \multicolumn{2}{|c|}{ Soxhlet } & \multicolumn{2}{|c|}{ Soxtec } & \multicolumn{2}{|c|}{ Sonication } \\
\hline & \% Recovery & $\% \mathrm{RSD}^{\mathrm{a}}$ & $\%$ Recovery & $\% \mathrm{RSD}^{\mathrm{a}}$ & $\%$ Recovery & $\% \mathrm{RSD}^{\mathrm{a}}$ & $\%$ Recovery & $\% \mathrm{RSD}^{\mathrm{a}}$ \\
\hline \multicolumn{9}{|l|}{ Alkylphenols } \\
\hline Phenol- $d_{5}$ & 71 & 12 & 78 & 36 & 66 & 14 & 79 & 4 \\
\hline Phenol & 69 & 11 & 76 & 21 & 56 & 20 & 67 & 7 \\
\hline 2-Methylphenol & 67 & 11 & 75 & 10 & 58 & 12 & 66 & 4 \\
\hline 4-Methylphenol & 71 & 9 & 74 & 9 & 69 & 20 & 71 & 5 \\
\hline 2,4-Dimethylphenol & 70 & 9 & 52 & 47 & 65 & 12 & 60 & 16 \\
\hline \multicolumn{9}{|l|}{ Halophenols } \\
\hline 2-Fluorophenol & 57 & 24 & 75 & 23 & 48 & 56 & 63 & 12 \\
\hline 2-Chlorophenol & 61 & 20 & 79 & 18 & 48 & 34 & 61 & 7 \\
\hline 2,4-Dichlorophenol & 78 & 10 & 95 & 5 & 71 & 14 & 76 & 3 \\
\hline 2,6-Dichlorophenol & 76 & 8 & 81 & 36 & 75 & 16 & 79 & 9 \\
\hline 4-Chloro-3-methylphenol & 80 & 8 & 91 & 8 & 81 & 15 & 88 & 3 \\
\hline 2,4,6-Trichlorophenol & 81 & 10 & 105 & 13 & 76 & 12 & 89 & 9 \\
\hline 2,4,5-Trichlorophenol & 86 & 8 & 103 & 12 & 85 & 13 & 83 & 3 \\
\hline 2,3,4,6-Tetrachlorophenol & 86 & 12 & 99 & 14 & 82 & 12 & 88 & 4 \\
\hline 2,4,6-Tribromophenol & 88 & 11 & 103 & 18 & 95 & 11 & 100 & 5 \\
\hline Pentachlorophenol & 86 & 12 & 97 & 20 & 84 & 16 & 92 & 6 \\
\hline
\end{tabular}


Table 4 (contd)




Table 4 (contd)




Table 4 (contd)

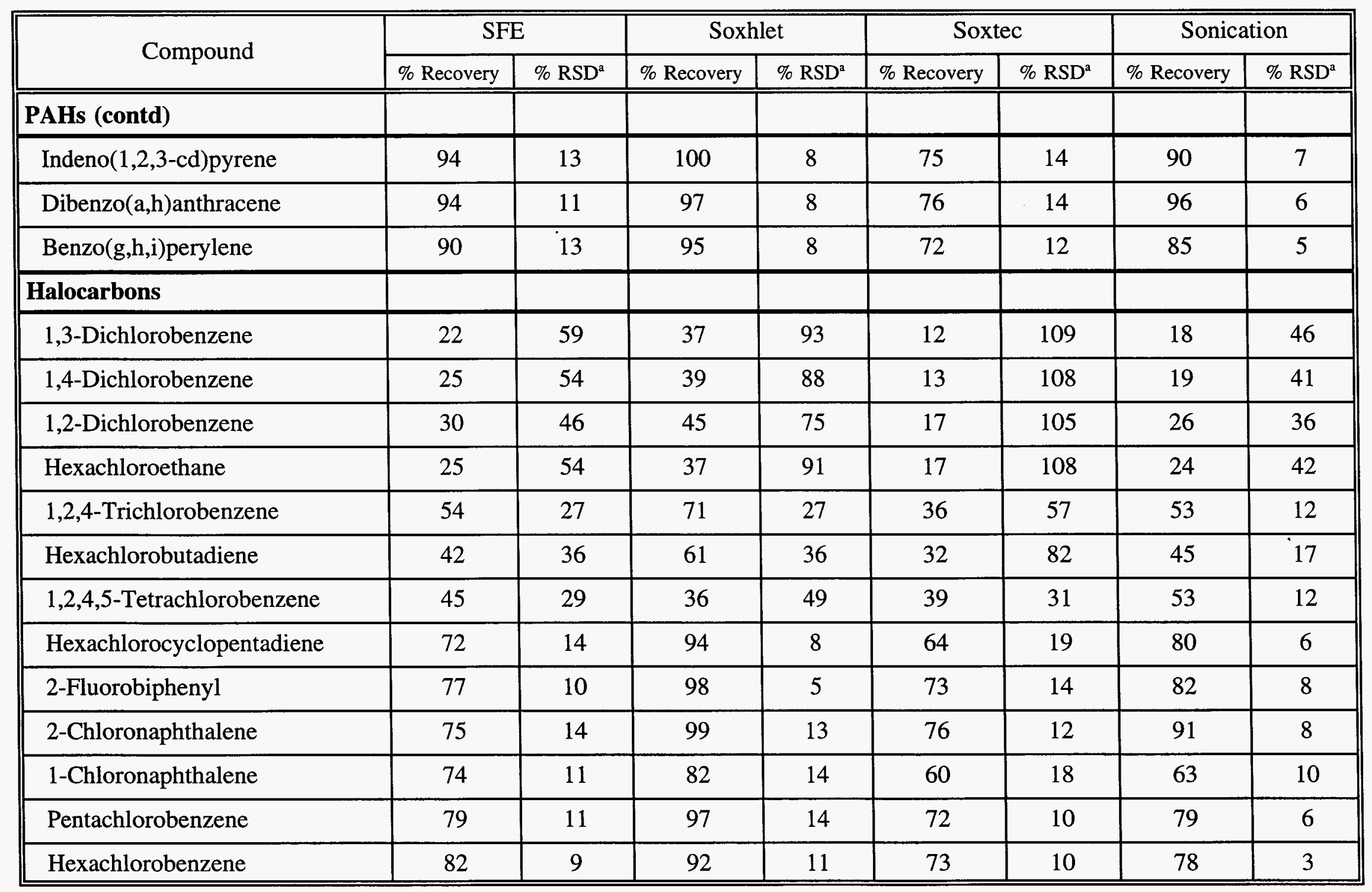


Table 4 (contd)

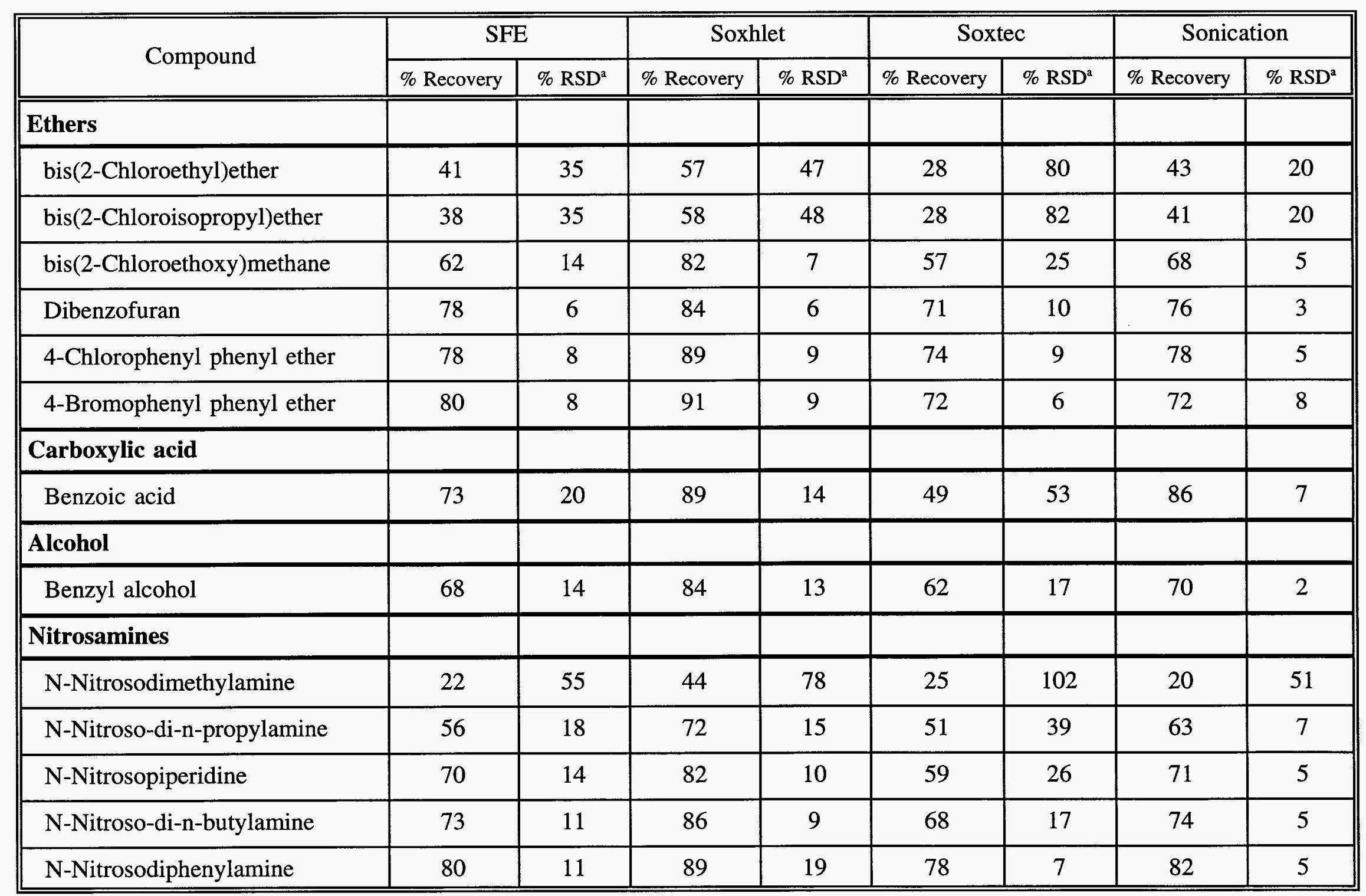


Table 4 (contd)




Table 4 (contd)

\begin{tabular}{|c|c|c|c|c|c|c|c|c|}
\hline \multirow{2}{*}{ Compound } & \multicolumn{2}{|c|}{ SFE } & \multicolumn{2}{|c|}{ Soxhlet } & \multicolumn{2}{|c|}{ Soxtec } & \multicolumn{2}{|c|}{ Sonication } \\
\hline & $\%$ Recovery & $\%$ RSD & $\%$ Recovery & $\% \mathrm{RSD}$ & $\%$ Recovery & $\%$ RSD & $\%$ Recovery & $\%$ RSD \\
\hline \multicolumn{9}{|l|}{ Pyridines } \\
\hline 2-Picoline & 31 & 41 & 31 & 56 & 22 & 86 & 38 & 22 \\
\hline $\operatorname{Dibenz}(\mathrm{a}, \mathrm{j})$ acridine & 54 & 23 & 81 & 10 & 68 & 16 & 86 & 6 \\
\hline \multicolumn{9}{|l|}{ Hydrazine } \\
\hline 1,2-Diphenylhydrazine & 77 & 13 & 86 & 21 & 76 & 11 & 79 & 13 \\
\hline \multicolumn{9}{|l|}{ Nitrobenzenes } \\
\hline Nitrobenzene- $d_{5}$ & 53 & 30 & 75 & 22 & 46 & 45 & 62 & 8 \\
\hline Nitrobenzene & 56 & 22 & 69 & 23 & 44 & 44 & 59 & 9 \\
\hline 2,6-Dinitrotoluene & 87 & 9 & 93 & 6 & 77 & 13 & 80 & 4 \\
\hline 2,4-Dinitrotoluene & 93 & 8 & 92 & 6 & 78 & 14 & 85 & 4 \\
\hline Pentachloronitrobenzene & 88 & 10 & 103 & 13 & 80 & 8 & 83 & 5 \\
\hline
\end{tabular}

${ }^{\mathrm{a}} \mathrm{RSD}=$ relative standard deviation 


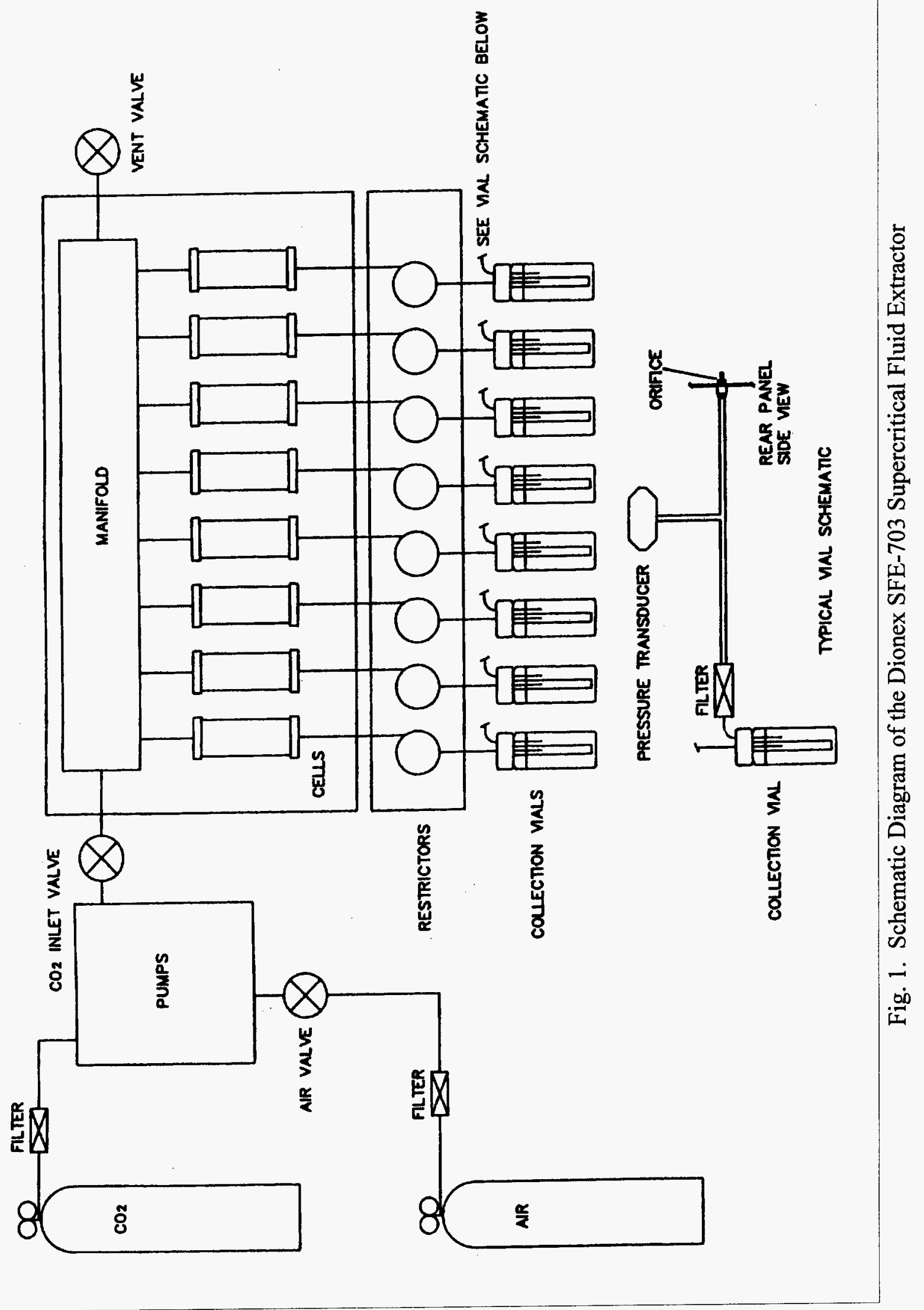




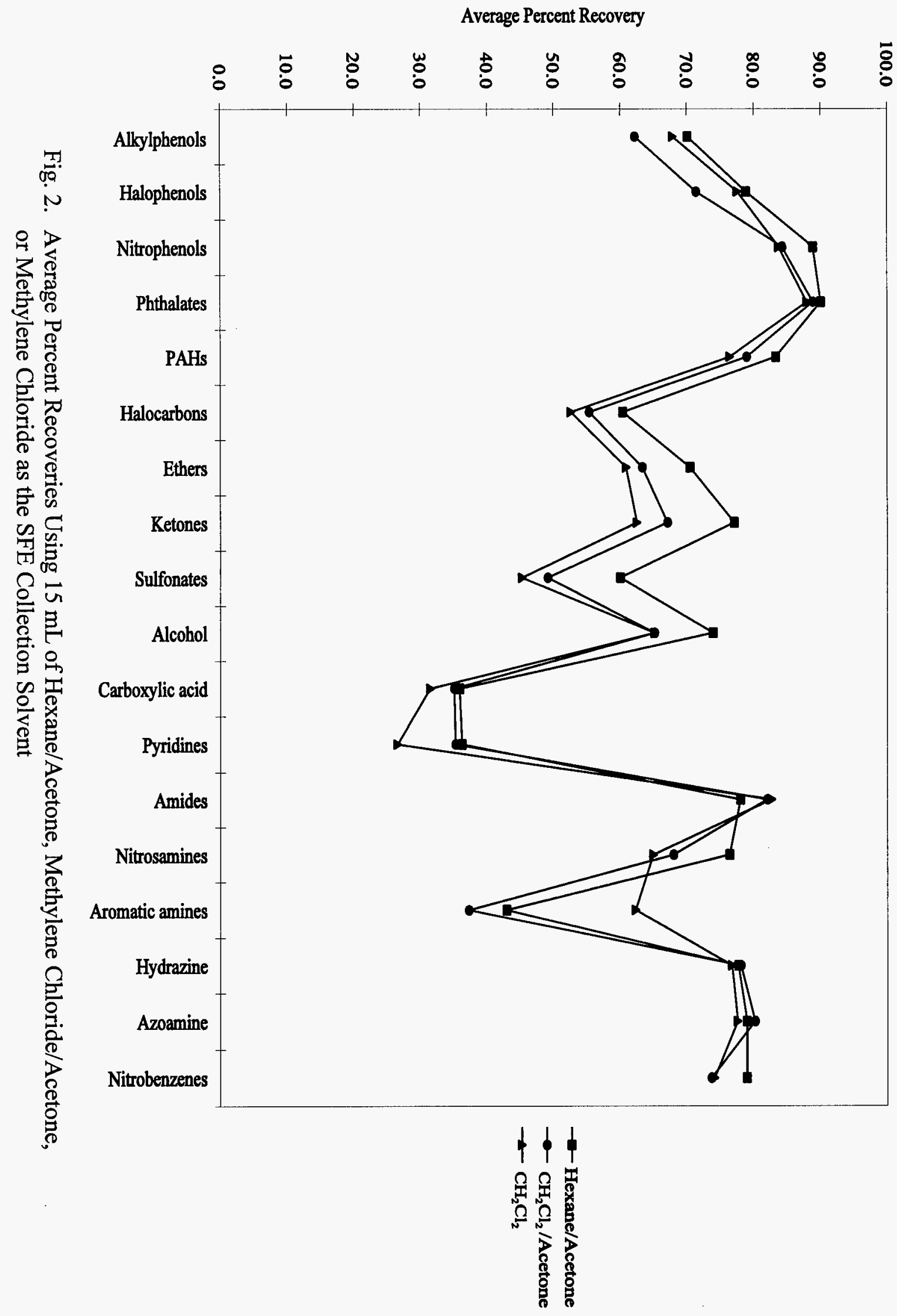




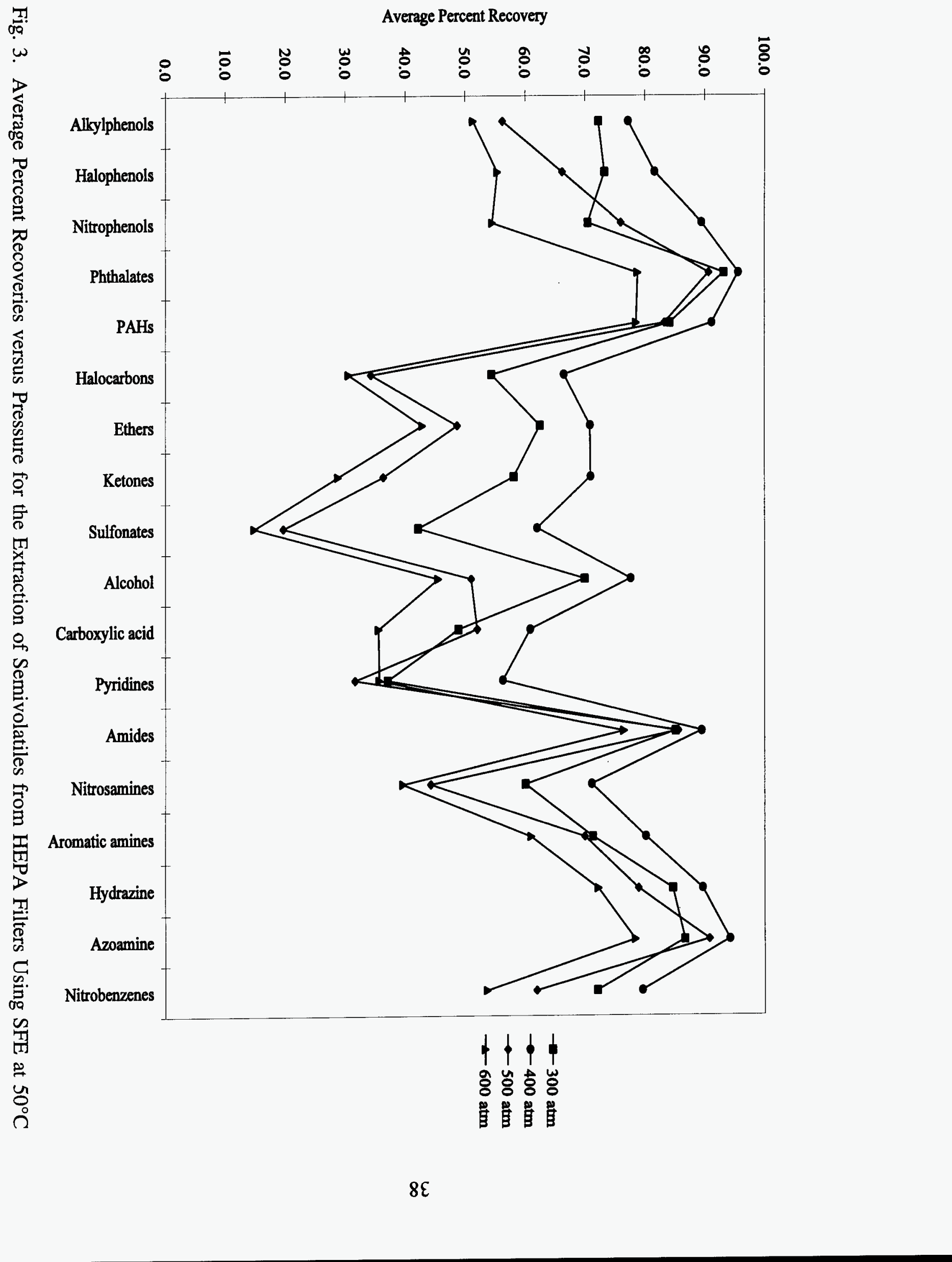




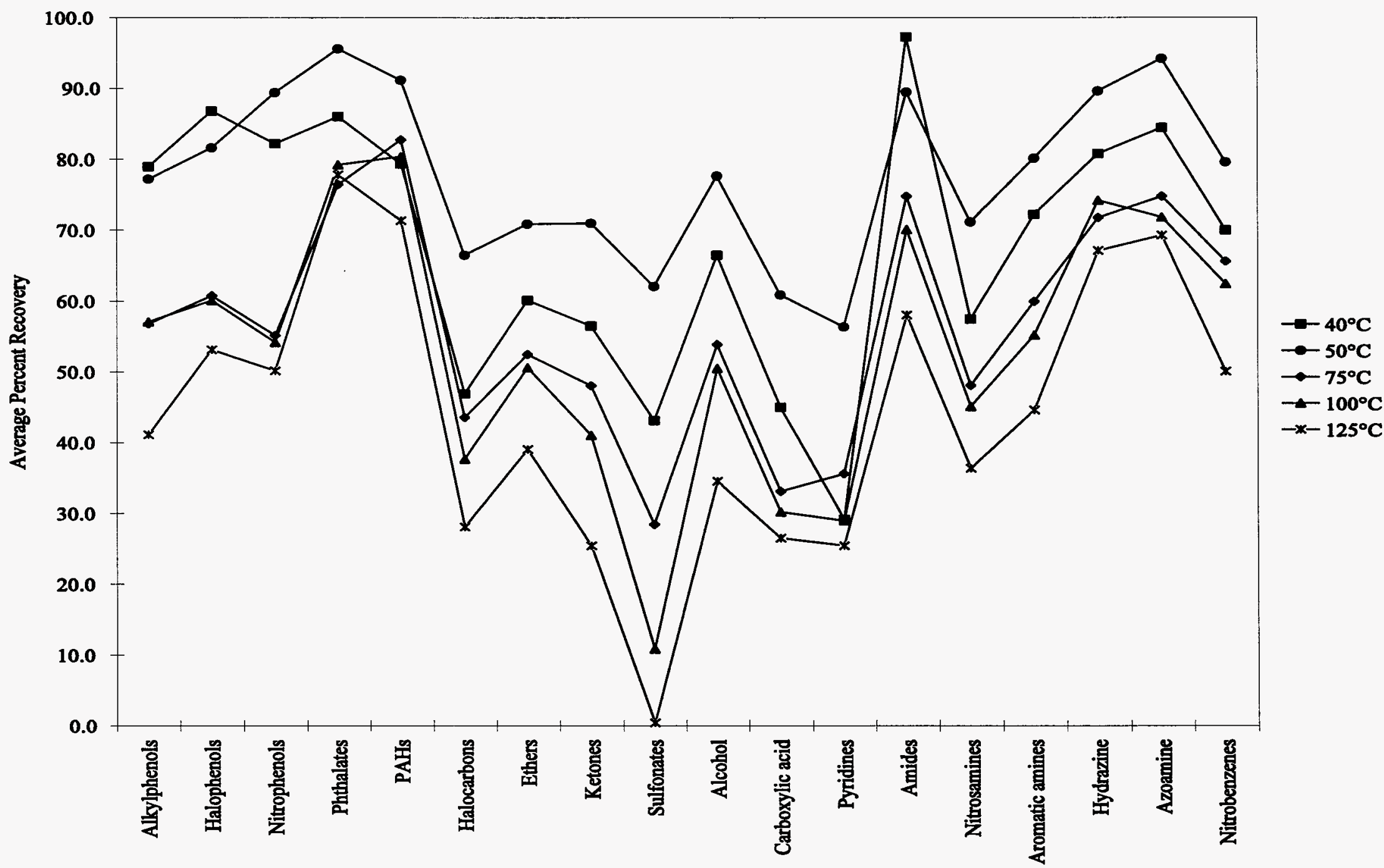

Fig. 4. Comparison of Average Recoveries versus Temperature for the Extraction of Semivolatiles from HEPA Filters Using SFE at $400 \mathrm{~atm}$ 







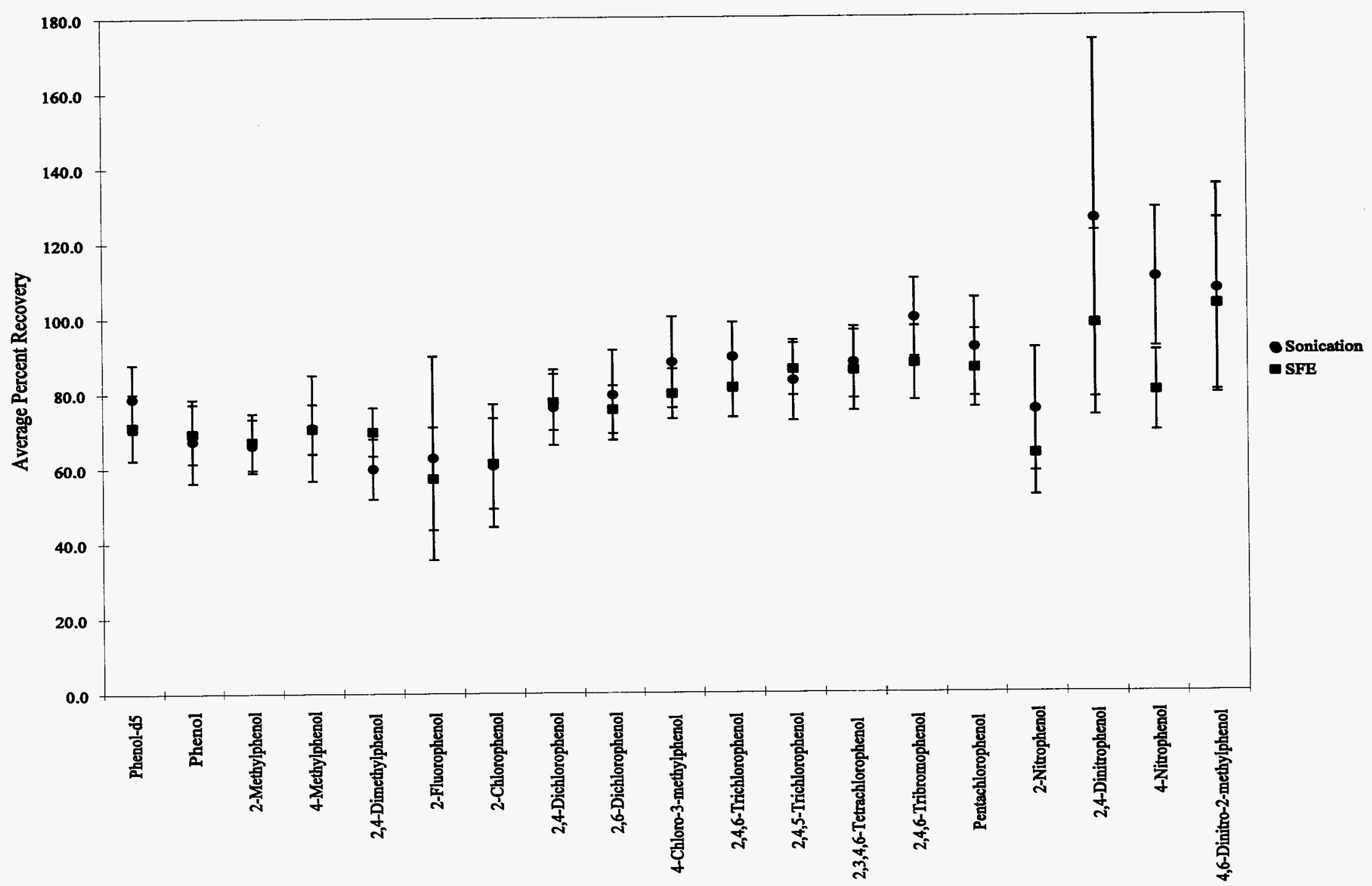

Fig. 6. Comparison between Sonication and SFE for the Extraction of Phenols from HEPA Filters 


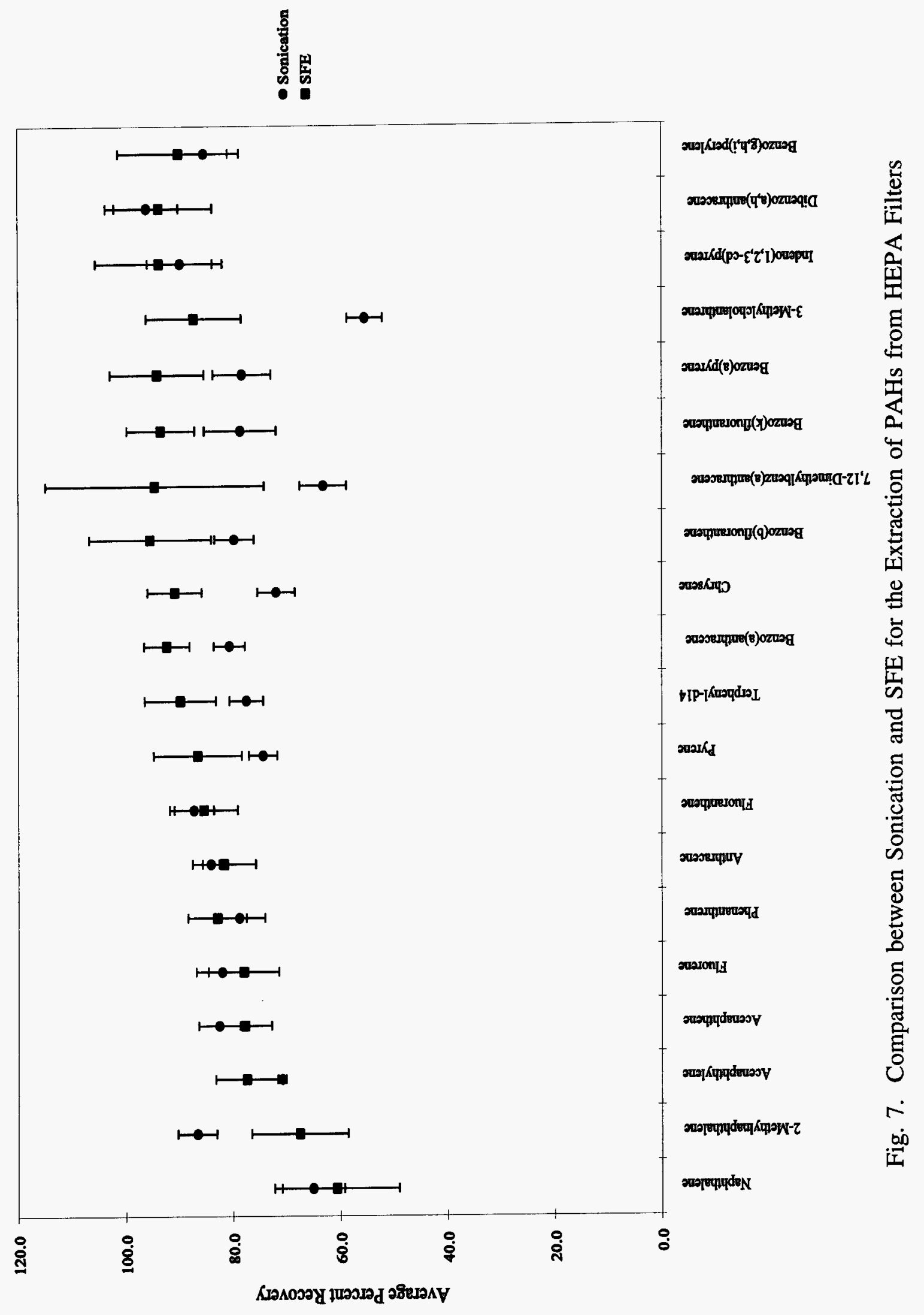




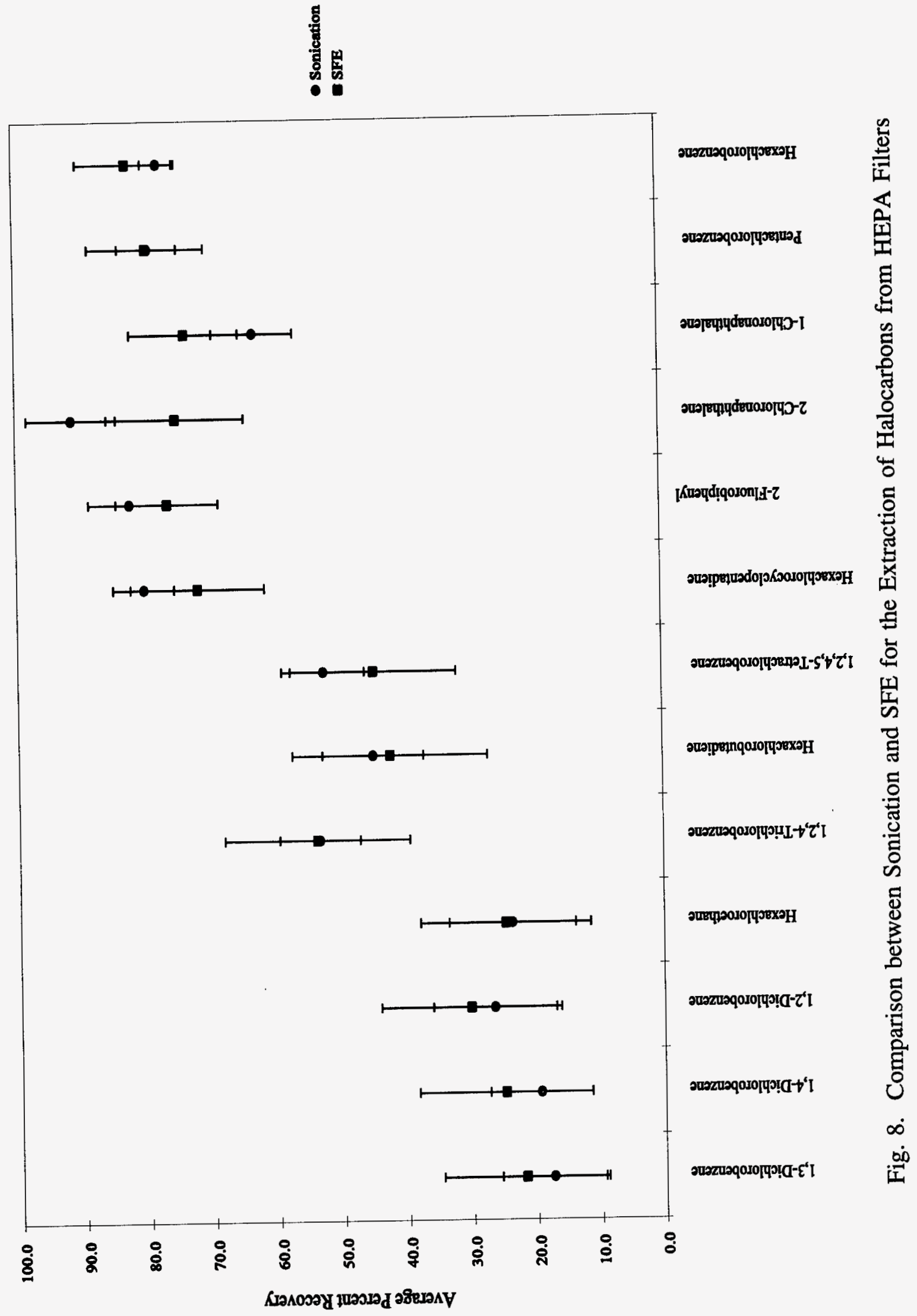







45

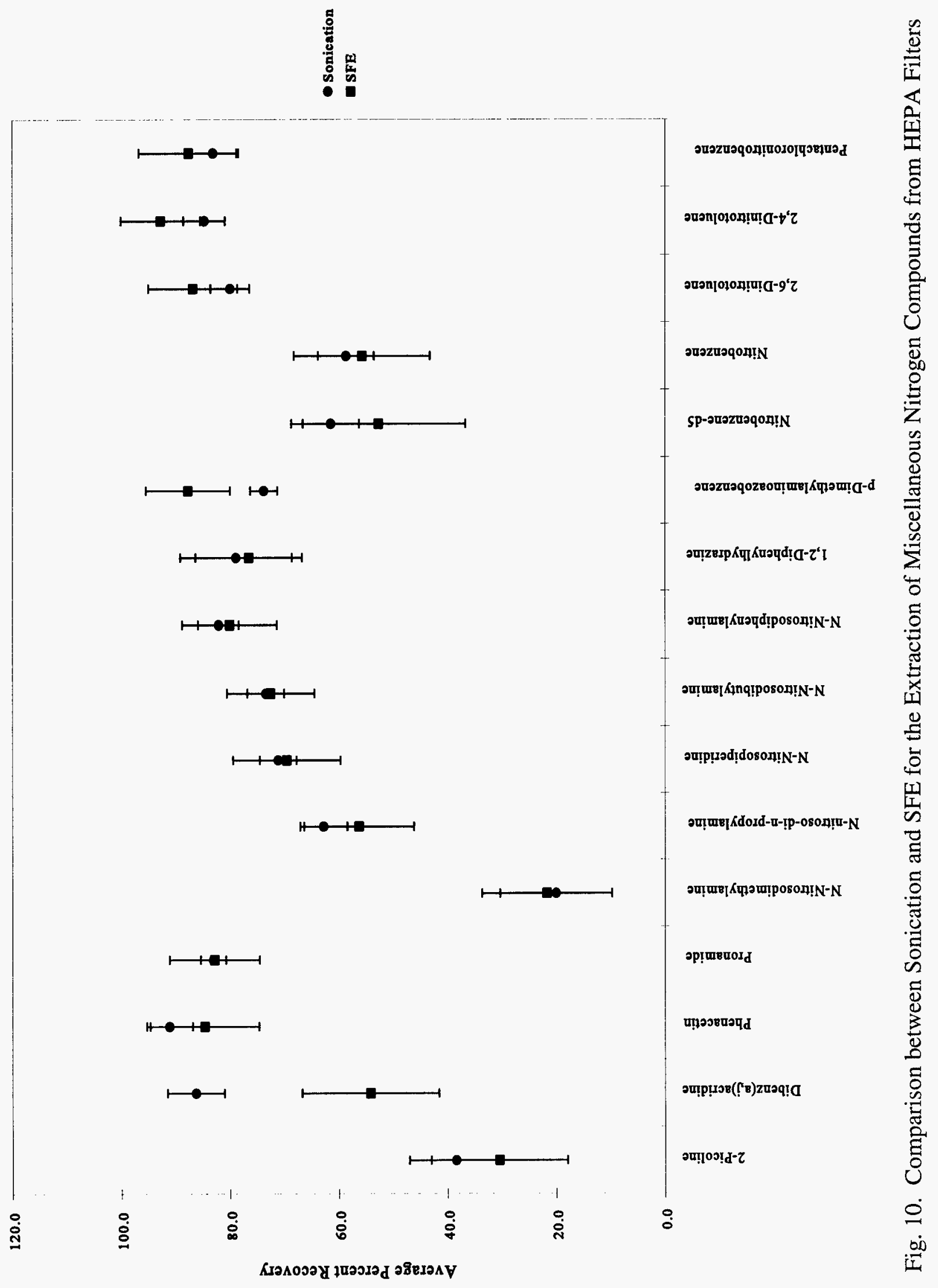




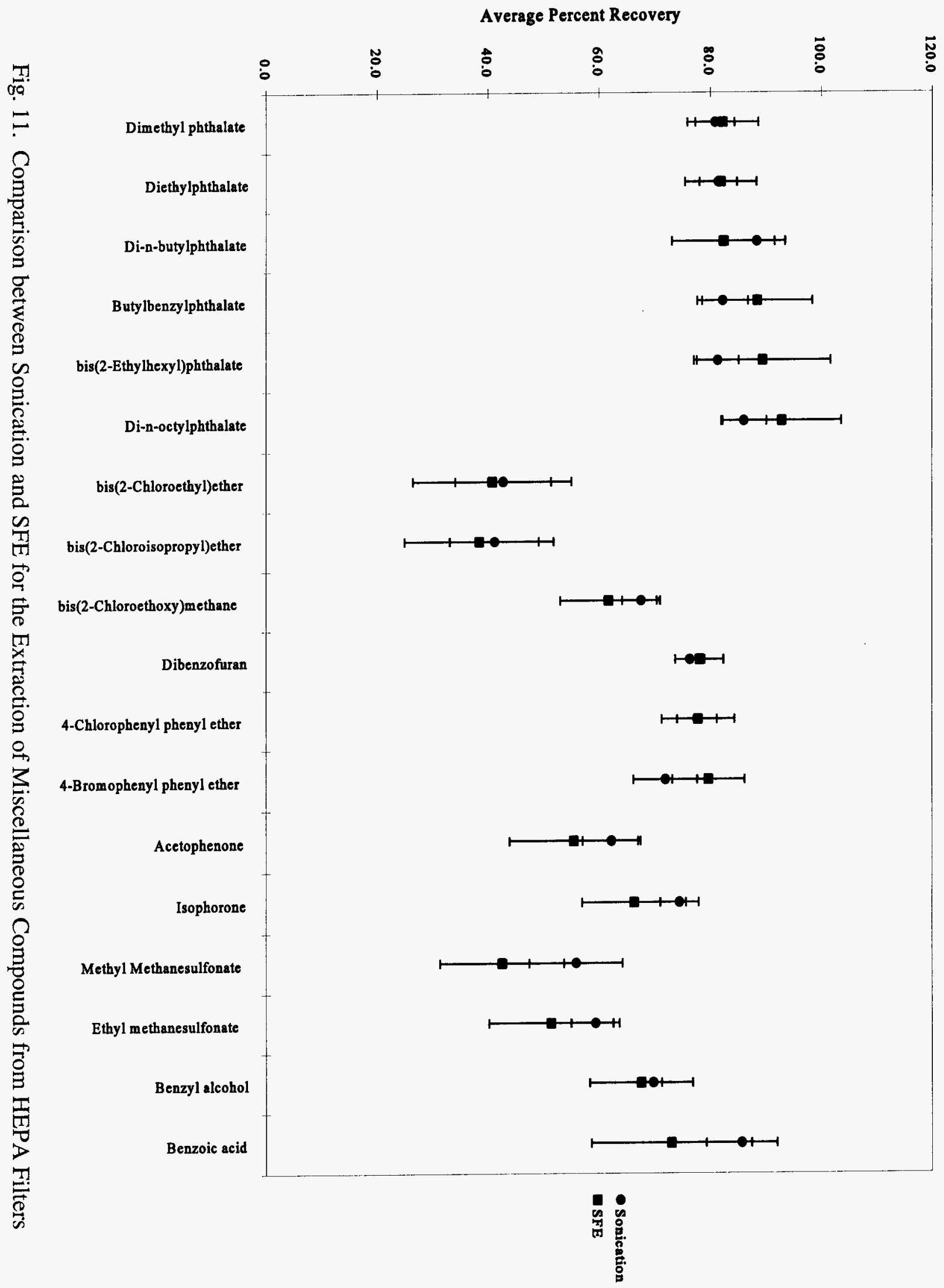




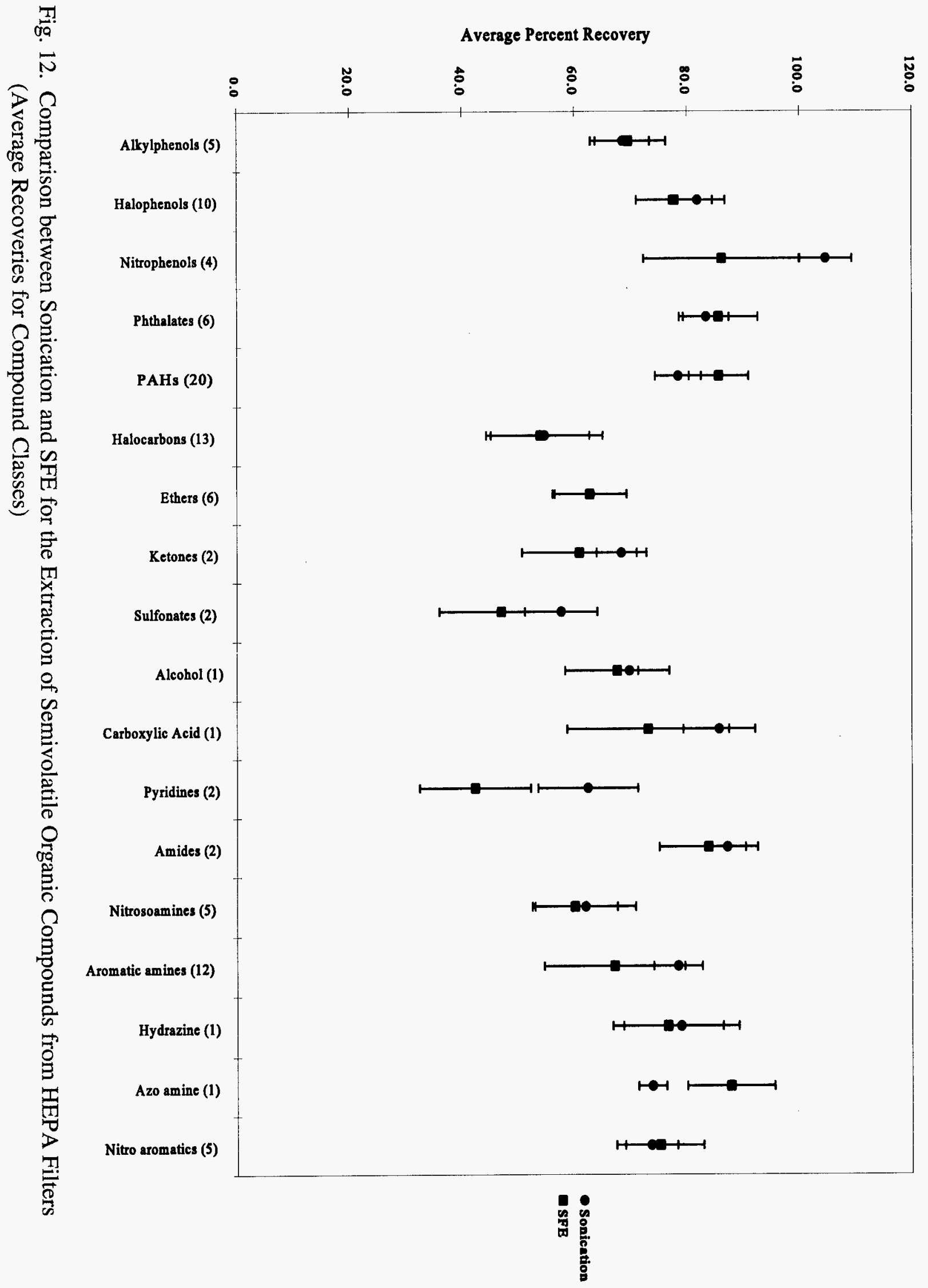




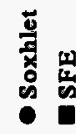

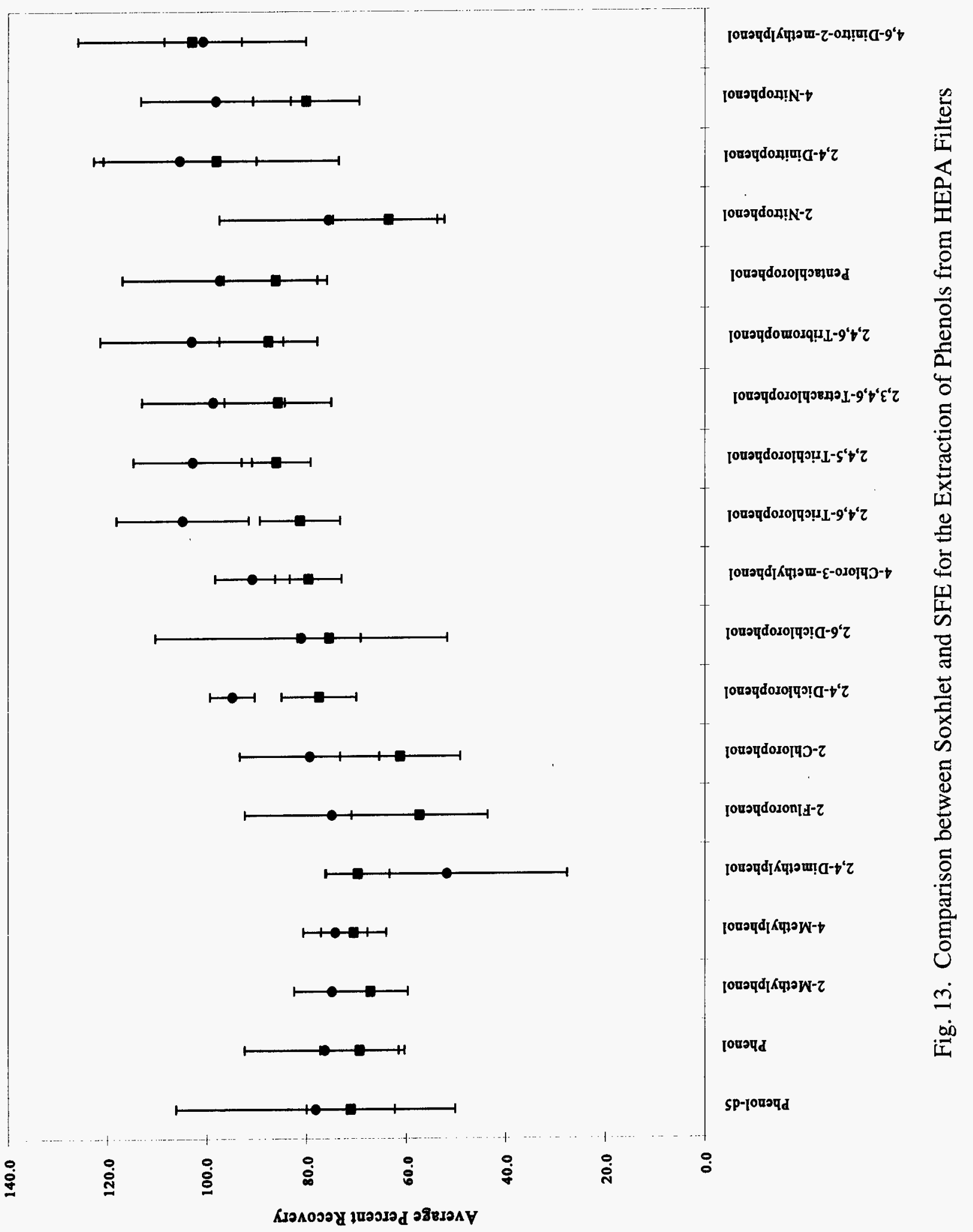




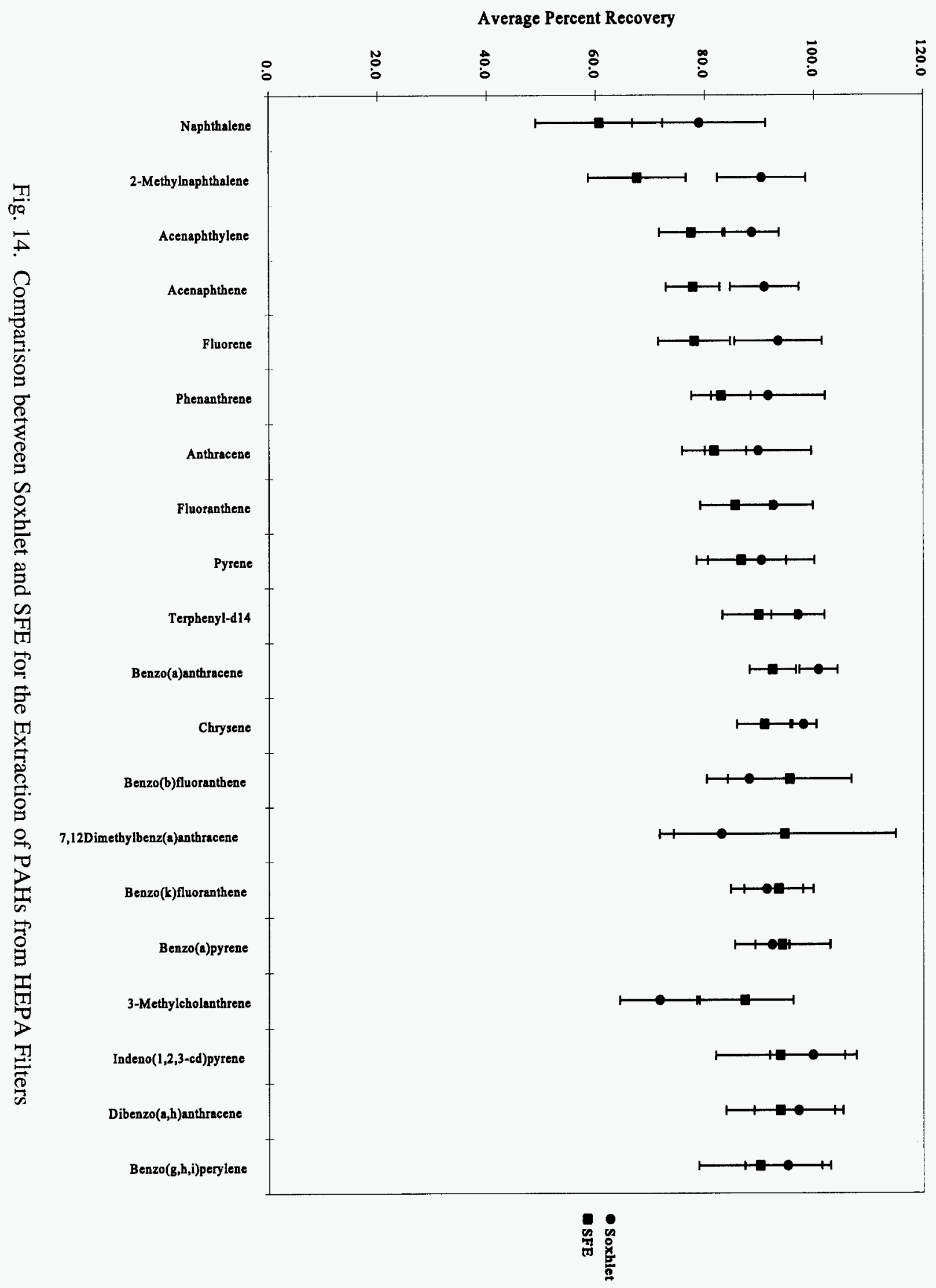




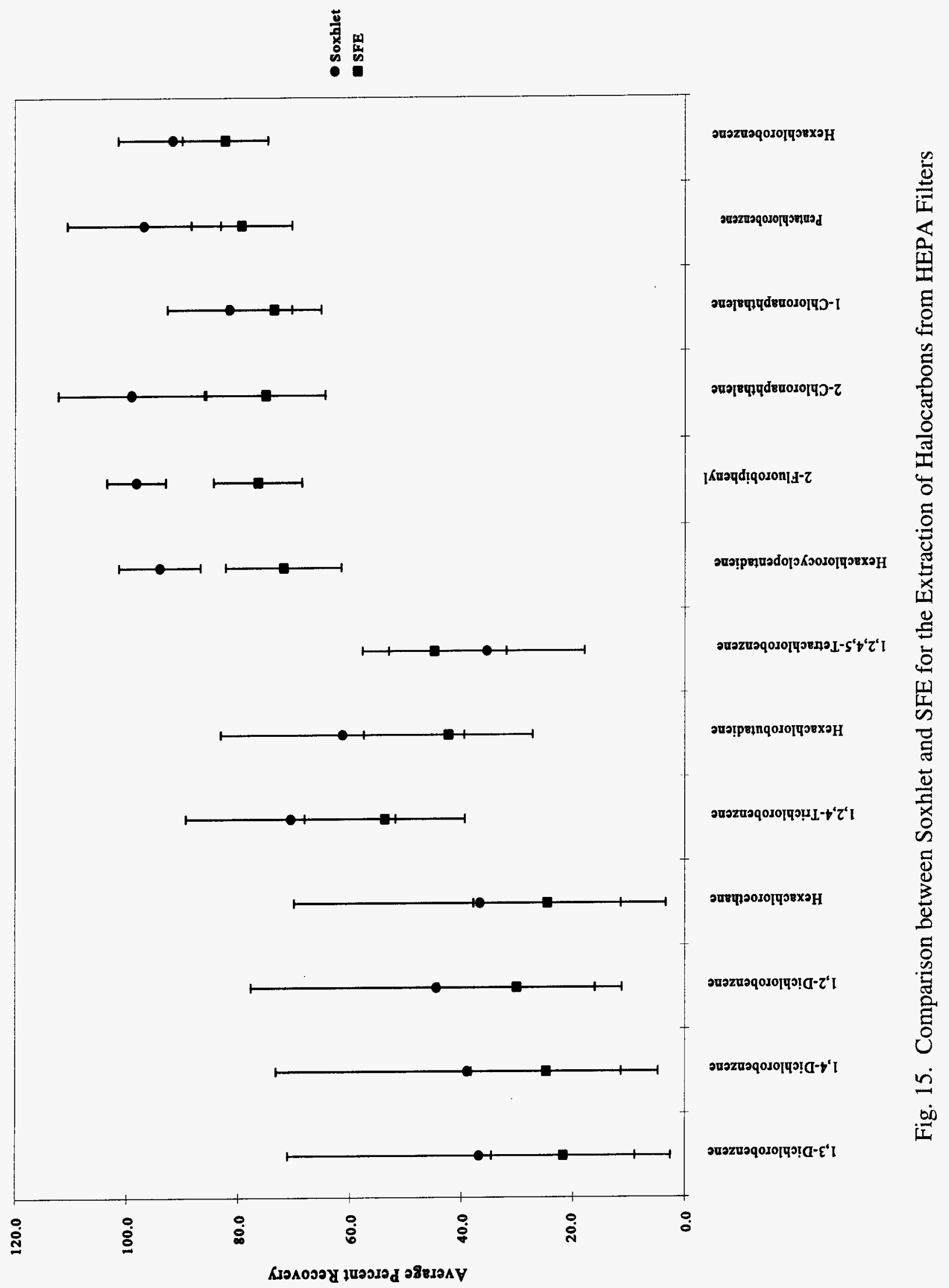




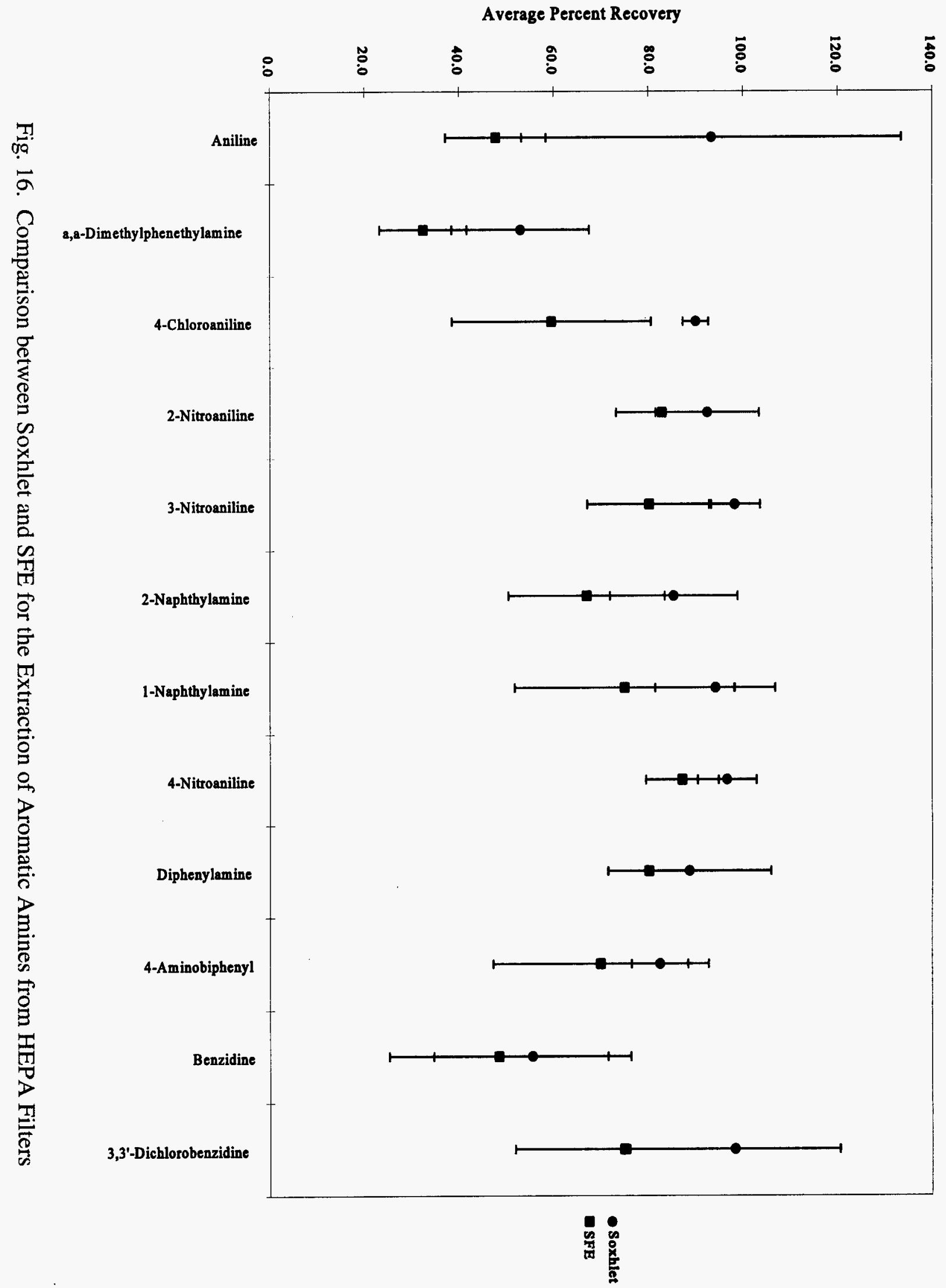




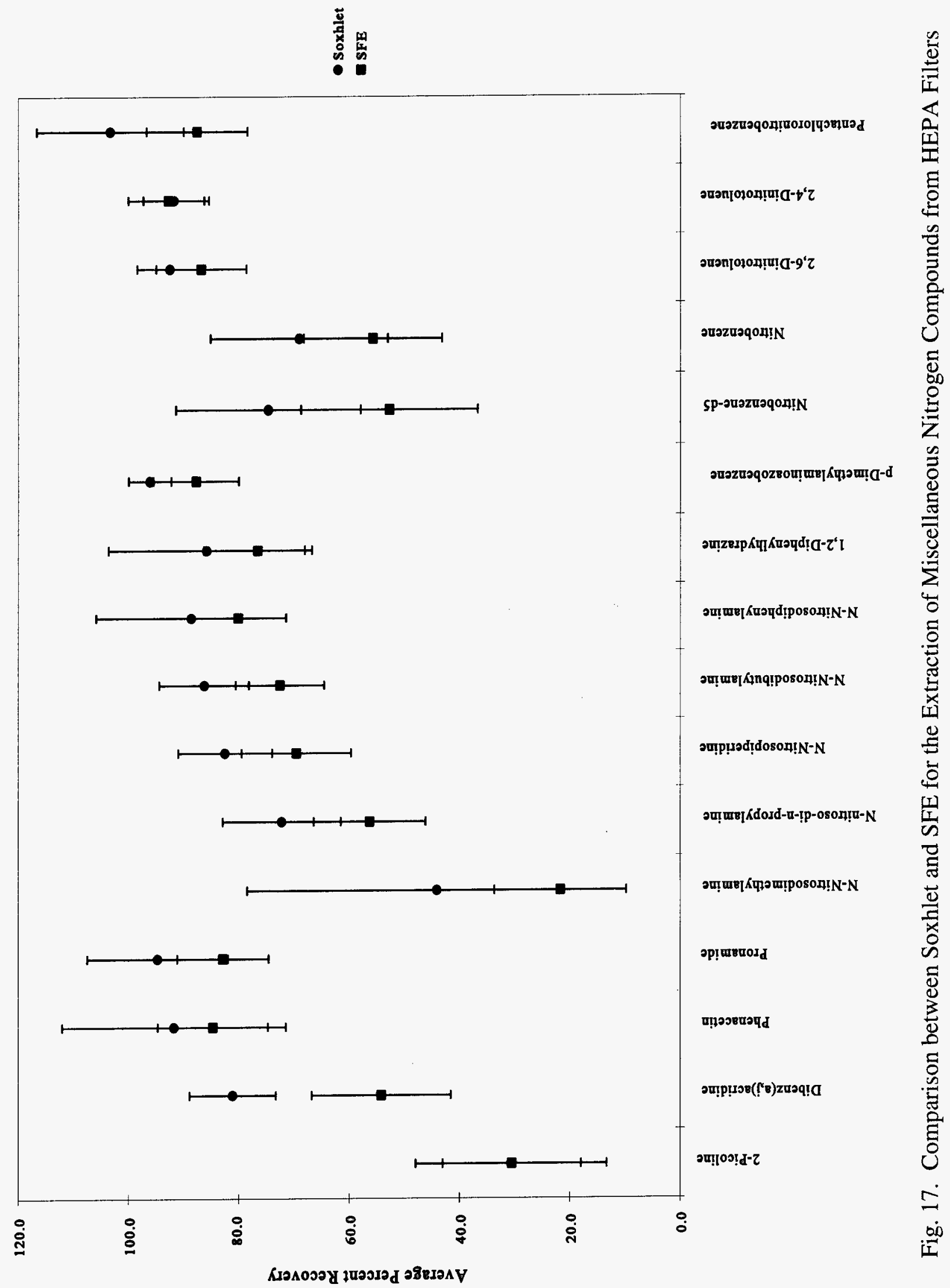




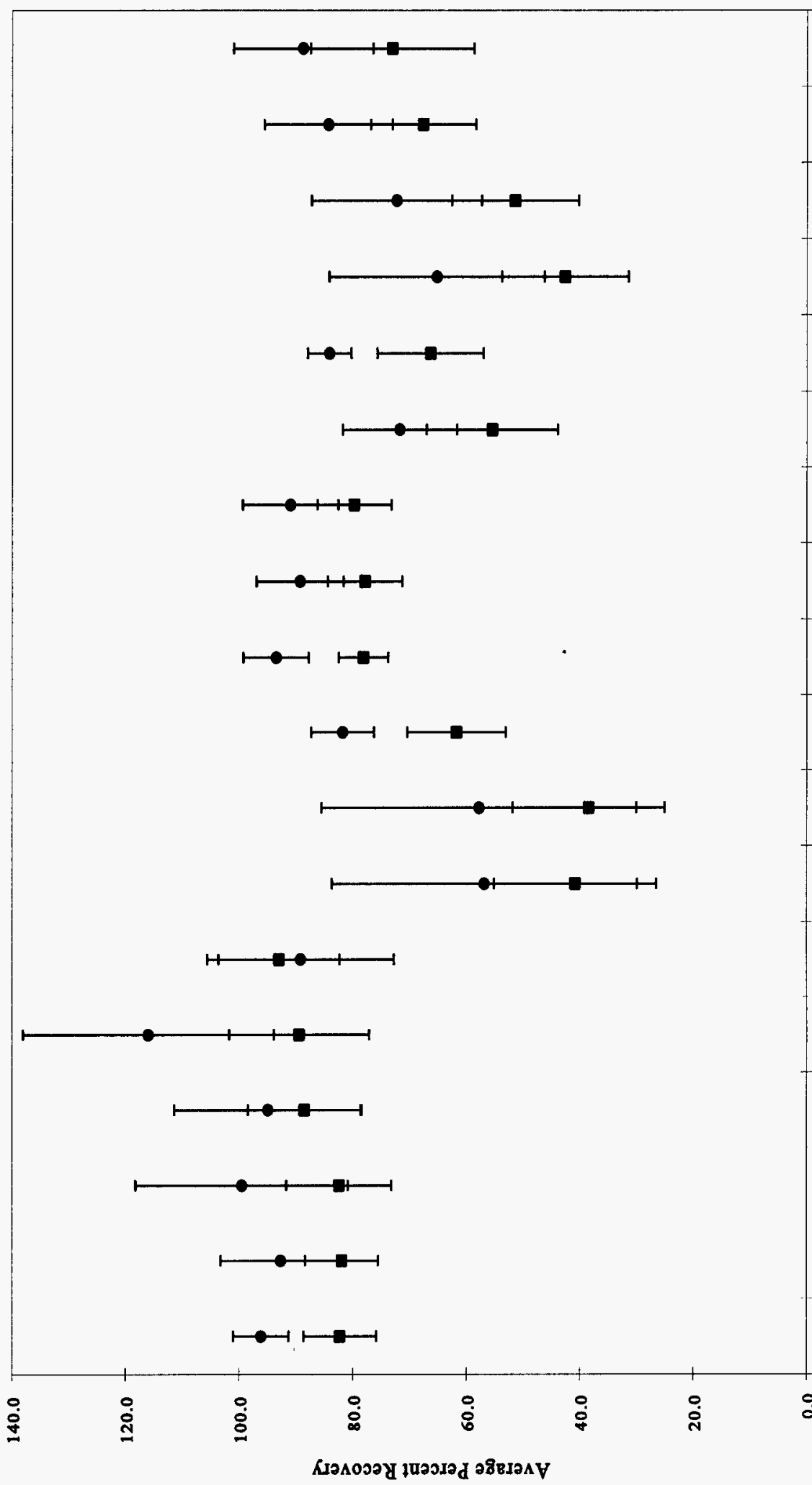

рเฺв गุozนอ

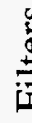

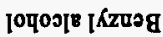

定

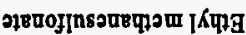

E

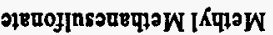

วu0]oप̣dos!

อuouəqdoฺว

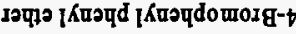

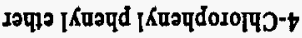

uвsnyozuəq!a

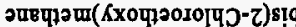

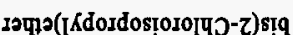

:



空

(1)

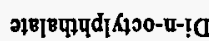

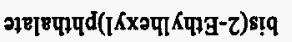

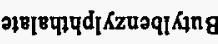



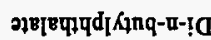



ә२в[вपापd [Кप१วш!्व

$\dot{\infty}$

$\dot{\infty}$ 


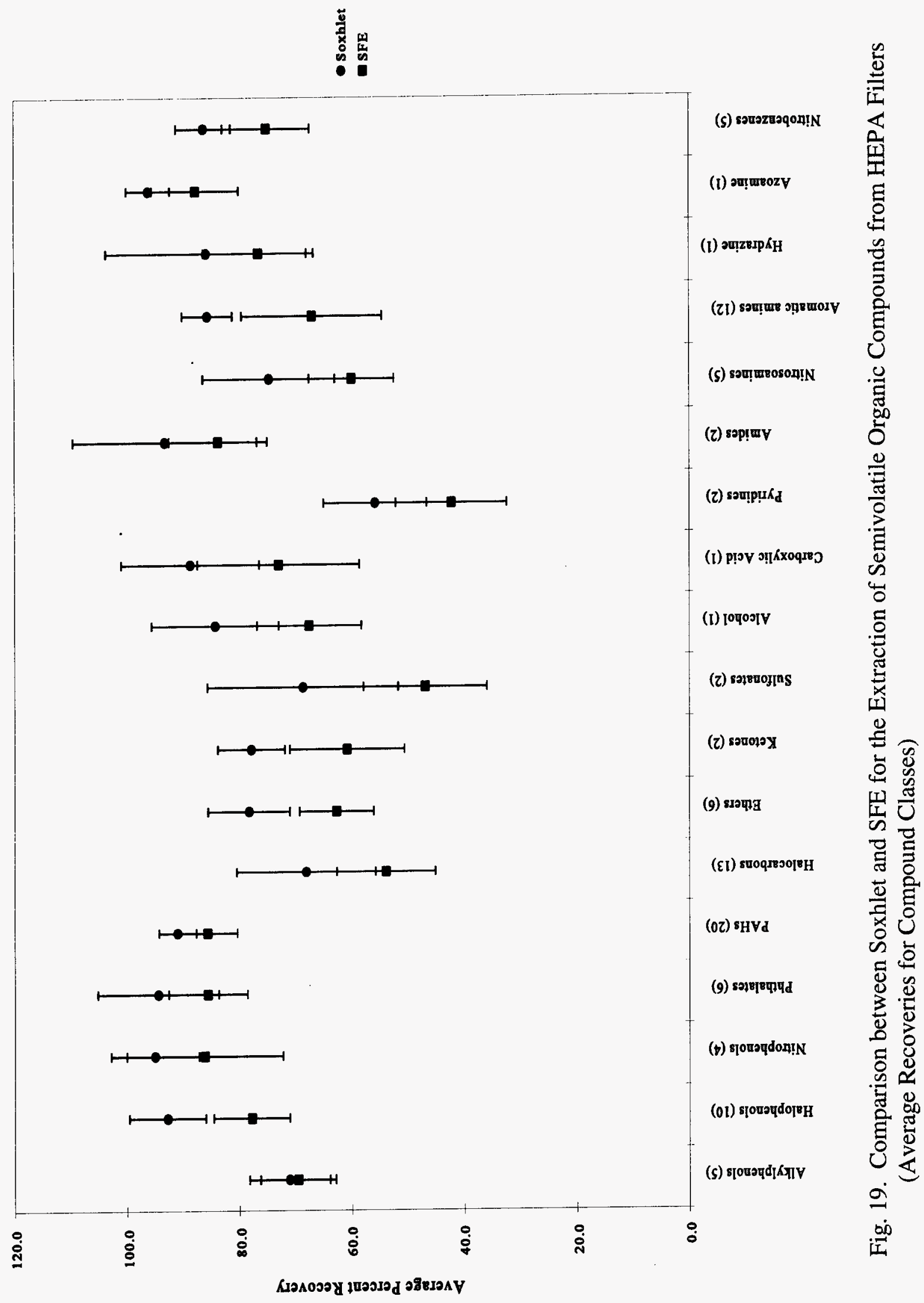









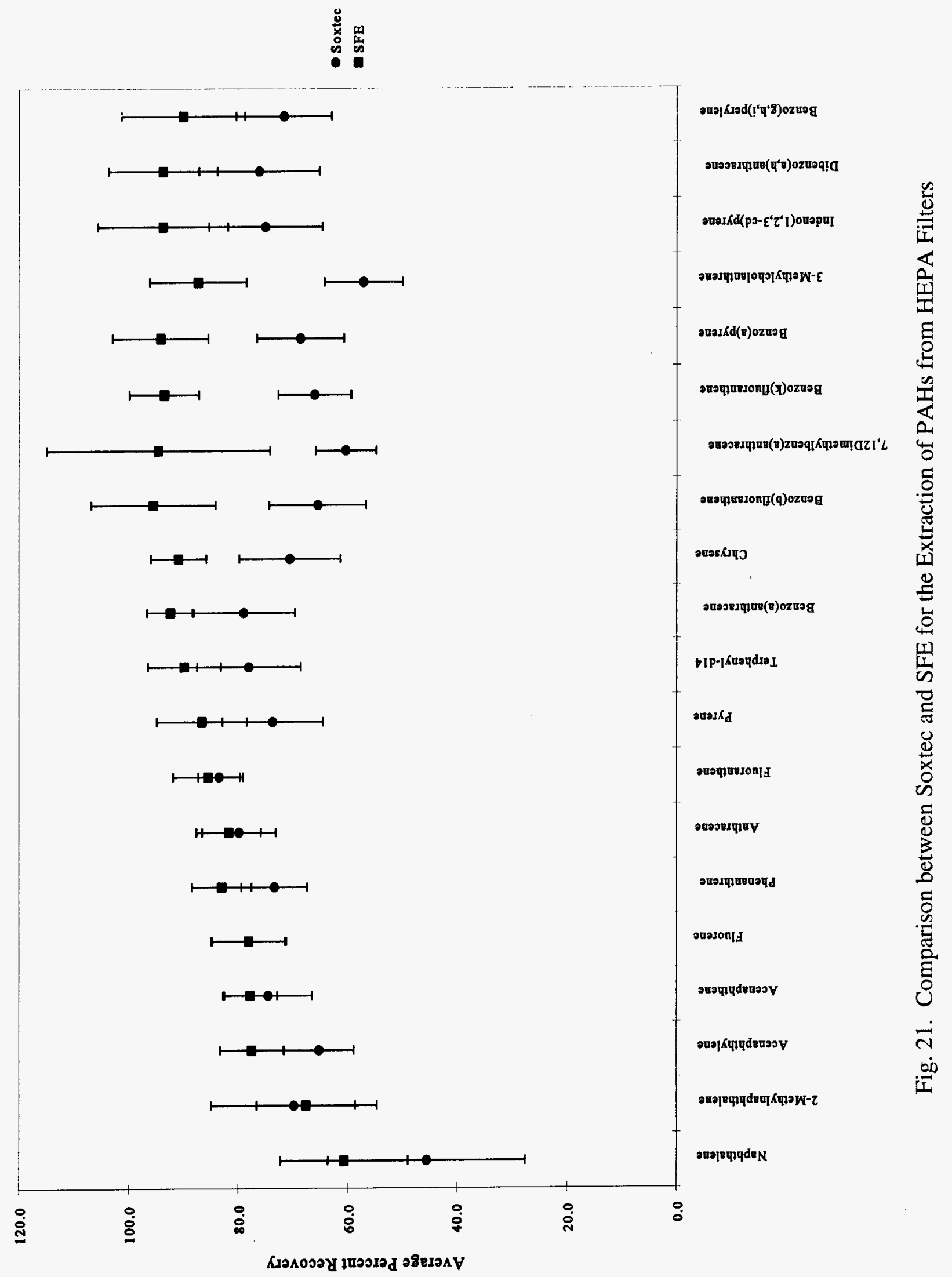




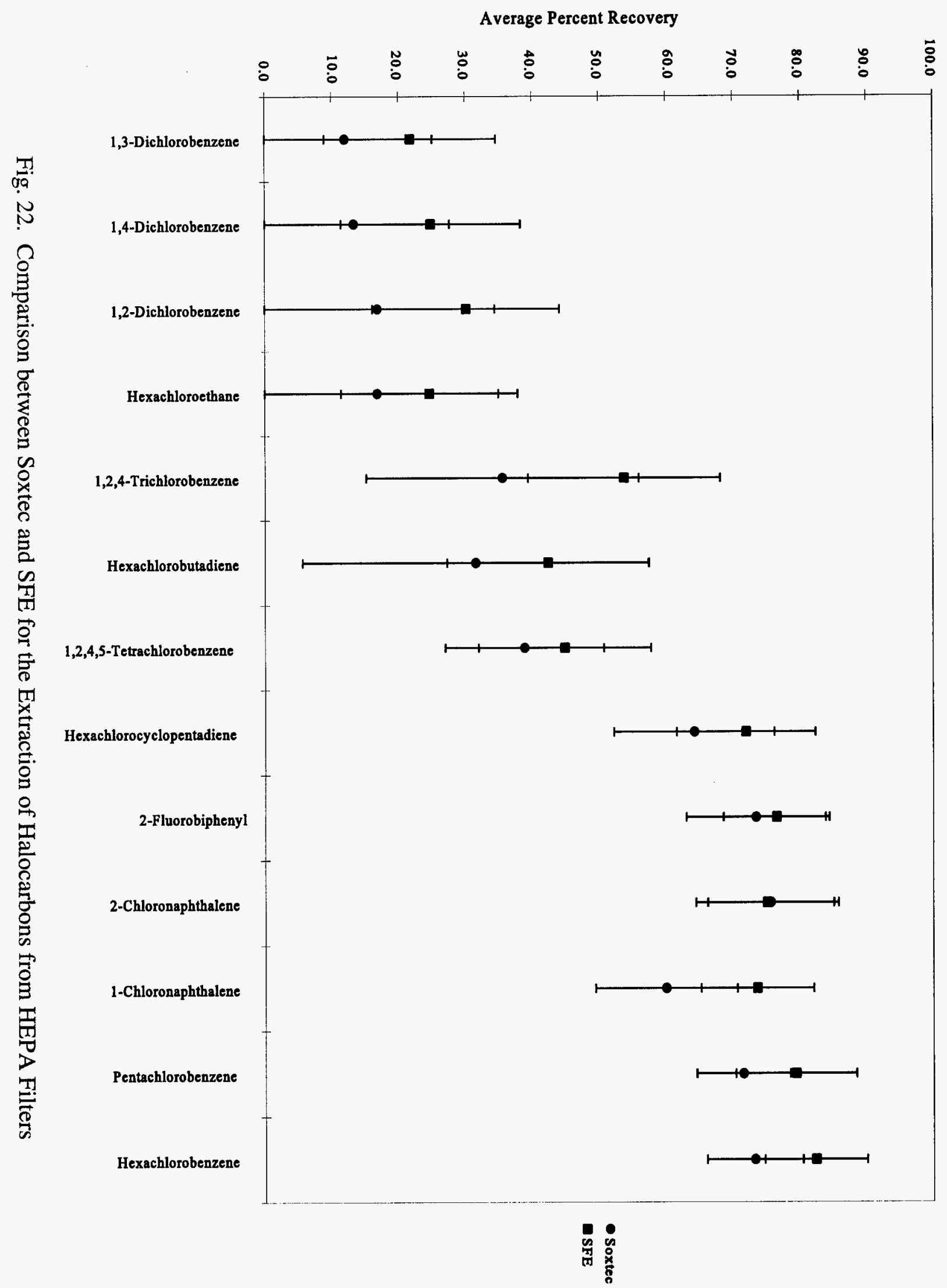




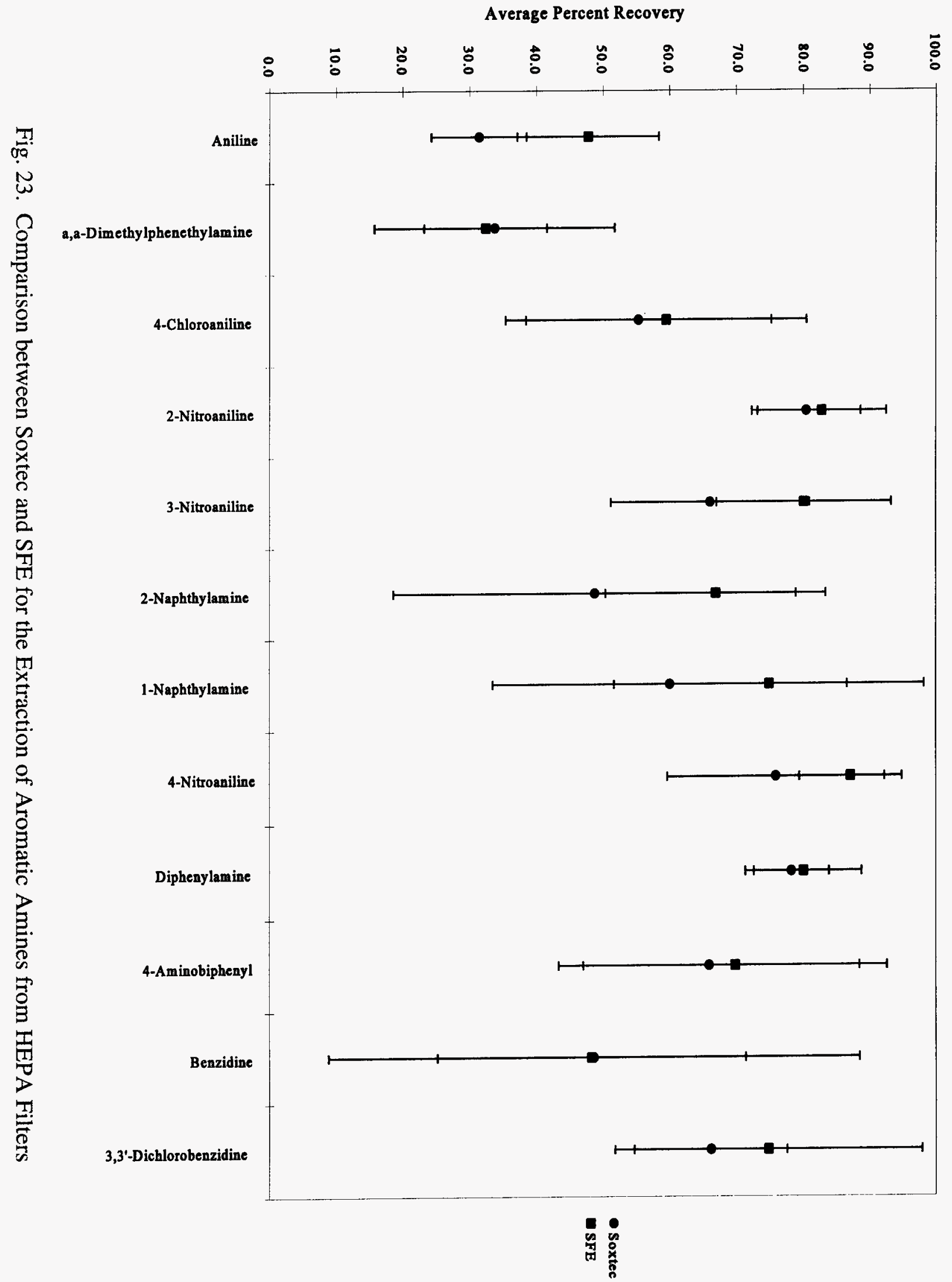




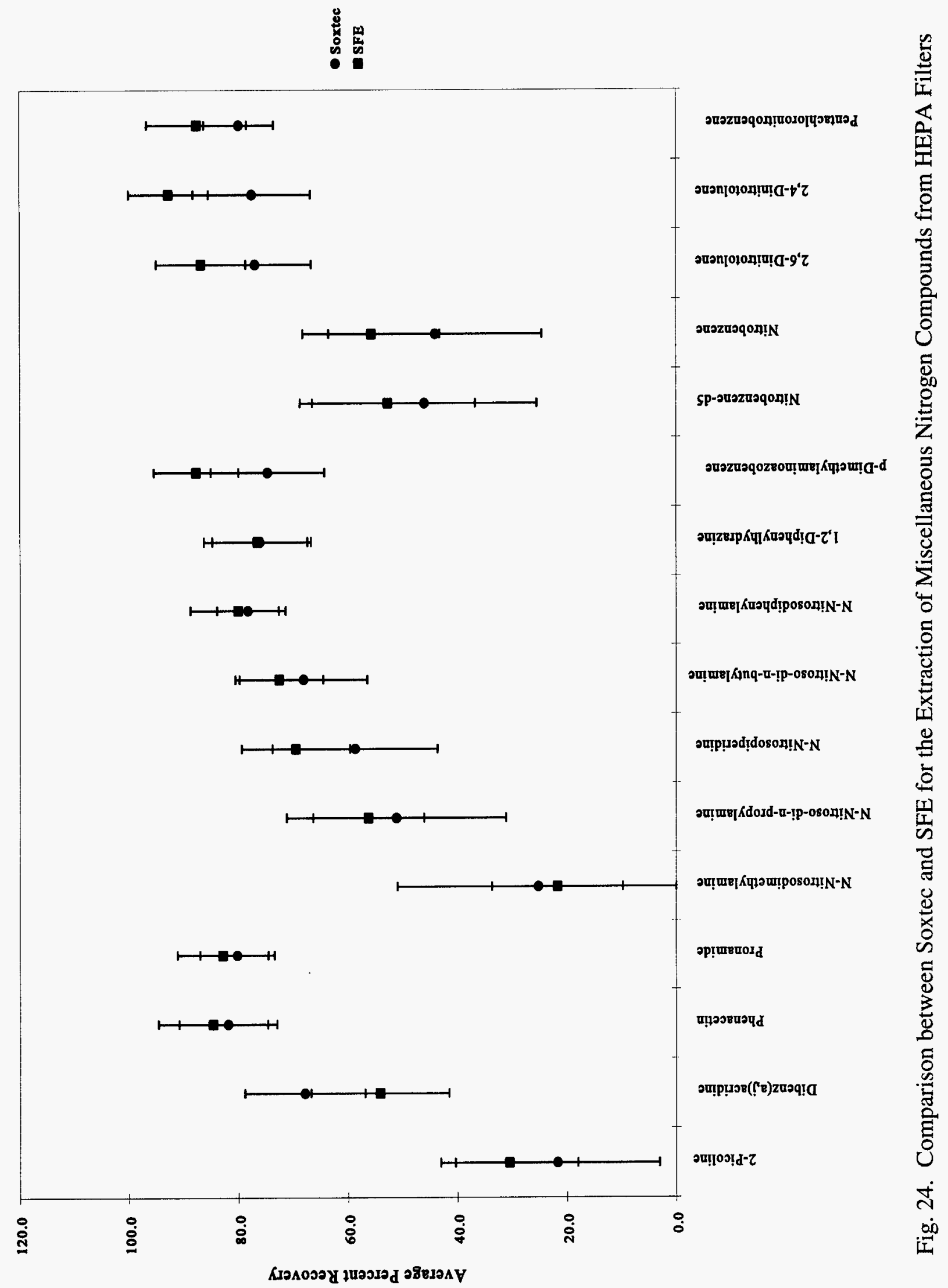




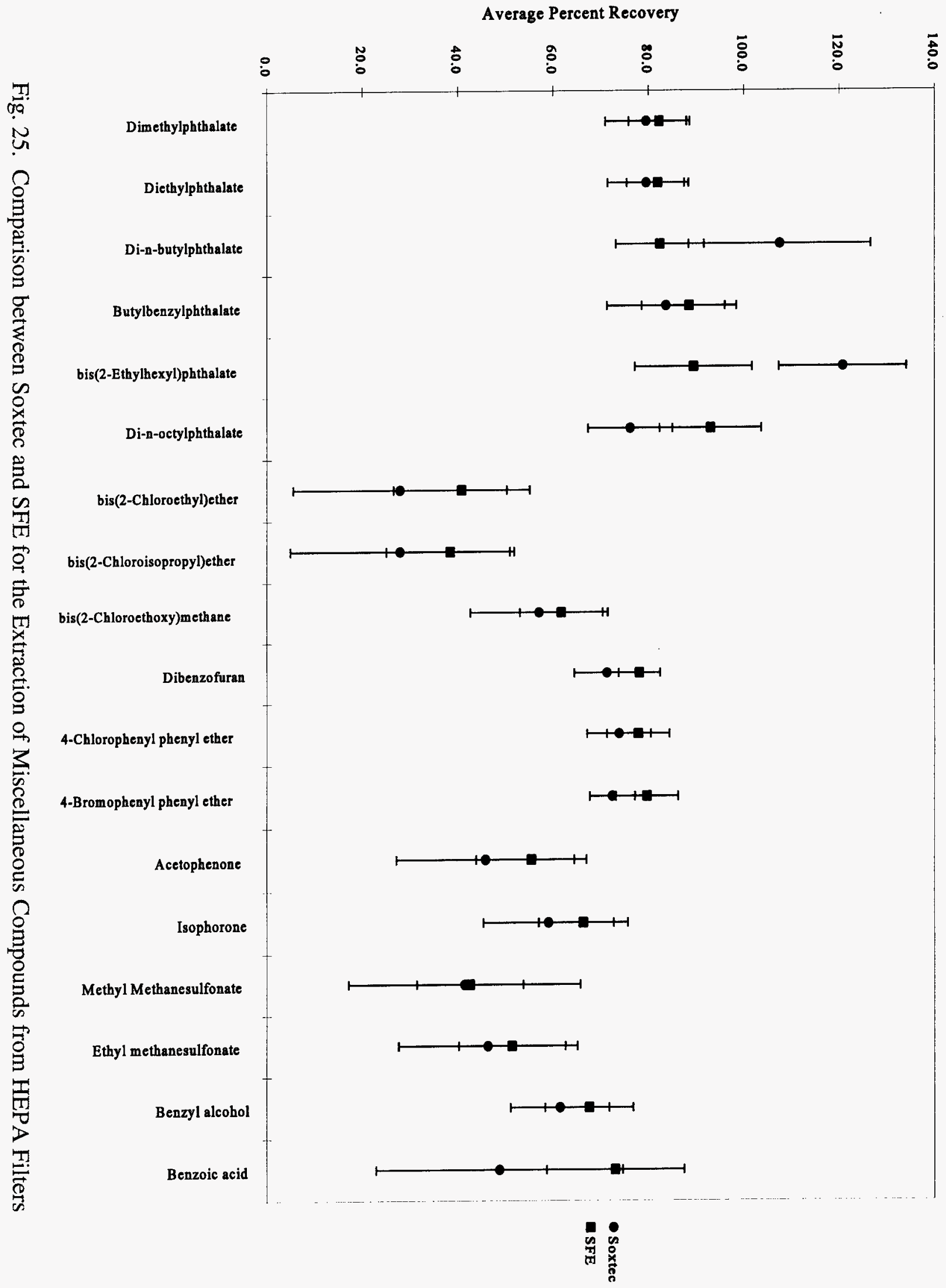




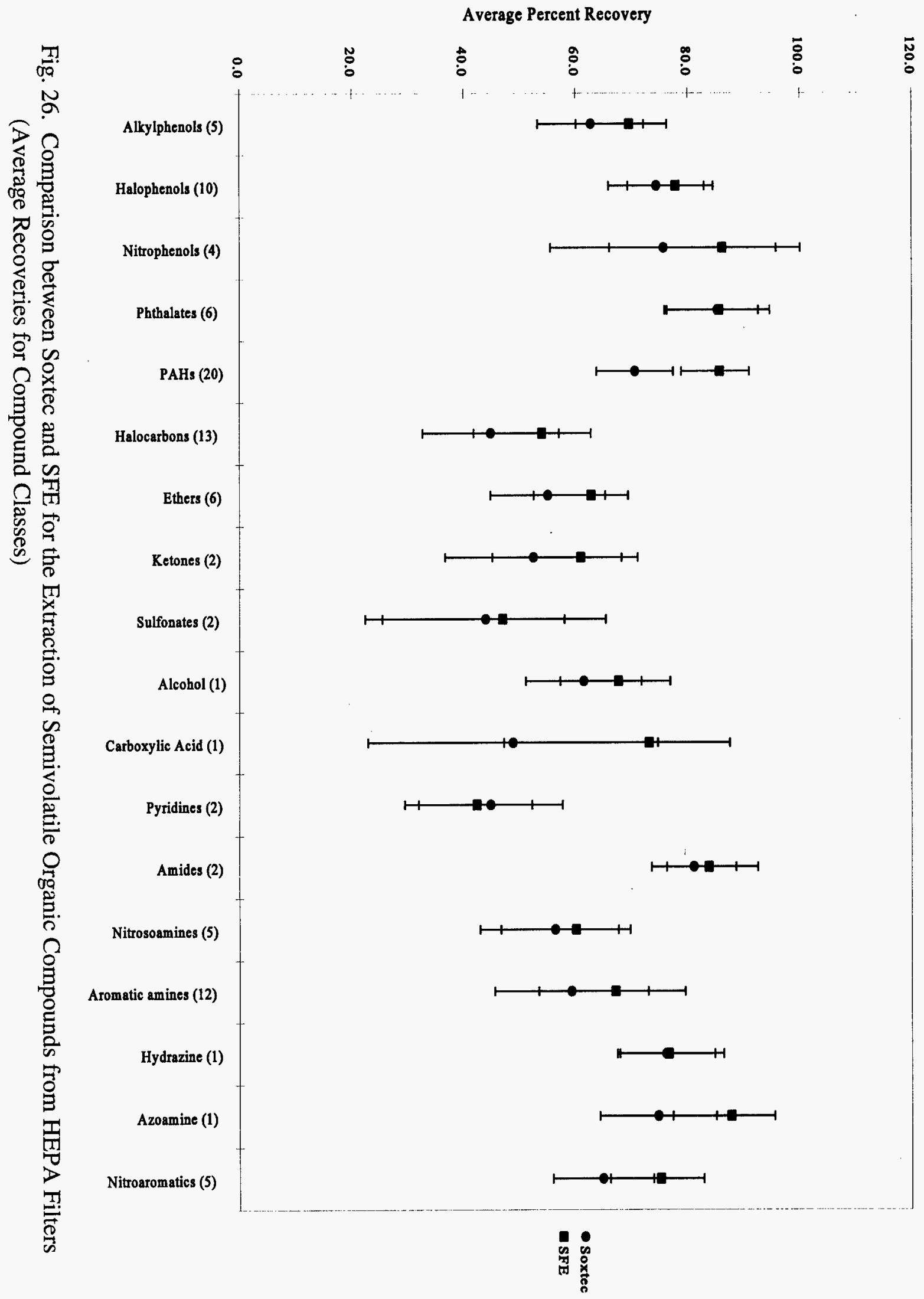


Distribution for ANL/ACL-97/6

Internal:

R. Agrawal

I. Ahmad

R. Alkire

I. Ambats

D. V. Applegate

J. G. Asbury

M. D. Atella

R. W. Bane

J. K. Bates

J. E. Battles

M. H. Bhattacharyya

S. K. Bhattacharyya

N. Bhatti

L. E. Boing

A. S. Boparai

D. L. Bowers

L. M. Boxberger

T. S. Bray

L. L. Briggs

B. S. Brown

A. R. Brunsvold

T. M. Burt

Z. Cai

D. J. Chaiko

Y. I. Chang

L. L. Chromizky

R. F. Coley

J. T. Collins

R. E. Combs

E. J. Croke

J. C. Cunnane

L. W. Deitrich

C. B. Dennis

M. H. Derbidge

S. Dieckman

D. R. Diercks

M. L. Dietz

R. W. Ditch

J. D. Ditmars

E. H. Dolecek

H. Drucker

F. J. Dudek

B. D. Dunlap
A. J. Dvorak

W. L. Ebert

R. A. Erck

M. Erdmann

M. D. Erickson

A. M. Essling

D. Ettinger

M. Farmer

F. Felicione

F. Y. Fradin

D. Freeman

B. R. T. Frost

E. K. Fujita

D. Geesaman

N. W. Golchert

A. J. Goldman

K. C. Goretta

D. G. Graczyk

J. W. Gramlich

C. Grandy

D. W. Green (10)

D. M. Gruen

W. H. Gunther

Y. Halpern

W. H. Hannum

J. B. Harkness

J. E. Harmon

B. Harvey

D. A. Haugen

J. J. Heiberger

R. R. Heinrich

J. E. Helt

W. F. Henning

J. Herman

I. Hlohowskyj

E. P. Horwitz

H. Huang

E. Huberman

D. R. Huff

E. A. Huff

A. B. Hull

M. J. Janik

D. O. Johnson
J. Johnson

P. L. Johnson

E. J. Karell

T. F. Kassner

A. L. Keebler

A. M. Kini

A. J. Kras

A. R. Krauss

J. R. Krsul

J. J. Laidler

T. A. Lang

K. H. Leong

L. G. LeSage

M. A. Lewis

P. C. Lindahl

M. J. Lineberry

C. D. Livengood

K. S. Macal

F. Markun

V. A. Maroni

J. J. Marr

F. J. Martino

H. F. McFarlane

C. C. McPheeters

C. A. Melendres

D. E. Moncton

L. R. Morss

G. D. Mosho

K. M. Myles

H. W. Myron

Z. Nagy

B. W. Nashold

L. A. Neimark

J. Noonan

J. W. O'Kelley

H. J. ONeill

M. M. Oldham

Y. Orechwa

D. Pancake

K. J. Parish

J. Park

C. V. Pearson

D. R. Pedersen 


$\begin{array}{lll}\text { J. P. Peerenboom } & \text { D. K. Schmalzer } & \text { W. M. Swift } \\ \text { M. J. Pellin } & \text { F. . Schmitz } & \text { B. S. Tani } \\ \text { W. H. Perry } & \text { J. F. Schneider } & \text { J. D. Taylor } \\ \text { P. J. Persiani } & \text { W. J. Shack } & \text { L. B. TenKate } \\ \text { R. Peters } & \text { S. Sharma } & \text { T. TenKate } \\ \text { M. Petrick } & \text { B. Shelton } & \text { R. J. Teunis } \\ \text { K. C. Picel } & \text { G. K. Shenoy } & \text { M. C. Thurnauer } \\ \text { R. B. Poeppel } & \text { C. M. Sholeen } & \text { D. Tomasko } \\ \text { A. J. Policastro } & \text { D. Singh } & \text { Z. Tomczuk } \\ \text { L. E. Price } & \text { J. G. Sleeth } & \text { A. Travelli } \\ \text { S. Rabidou } & \text { D. L. Smith } & \text { Y. Tsai } \\ \text { A. C. Raptis } & \text { D. L. Smith } & \text { G. F. Vandegrift } \\ \text { D. M. Ray } & \text { F. P. Smith } & \text { B. Verhaaren } \\ \text { C. B. Reed } & \text { L. L. Smith } & \text { L. C. Walters } \\ \text { G. T. Reedy } & \text { R. K. Smither } & \text { D. W. Warren } \\ \text { C. A. Reilly } & \text { C. T. Snyder } & \text { R. W. Weeks } \\ \text { P. D. Roach } & \text { M. A. Sodaro } & \text { J. Wescott } \\ \text { M. J. Robinet } & \text { B. W. Spencer } & \text { M. L. Wesely } \\ \text { C. M. Rock } & \text { V. C. Stamoudis } & \text { R. E. Winans } \\ \text { R. Rosenberg } & \text { V. Steed } & \text { R. D. Wolson } \\ \text { L. E. Ross } & \text { C. M. Stevens } & \text { J. L. Woodring } \\ \text { C. S. Sabau } & \text { R. L. Stevens } & \text { R. A. Wynveen } \\ \text { J. I. Sackett } & \text { R. V. Strain } & \text { A. C. Young } \\ \text { N. F. Sather } & \text { S. B. Strasser } & \text { TIS Files } \\ \text { P. L. Scalingi } & \text { W. E. Streets } & \end{array}$

External:

DOE-OSTI (2)

ANL-E Library

ANL-W Library

Manager, Chicago Operations Office, DOE

A. Bindokas, DOE-CH

J. C. Haugen, DOE-CH

R. E. Lang, DOE-CH

E. Mulford, DOE-CH

A. L. Taboas, DOE-CH

B. J. Zeigler, DOE-CH

Chemical Technology Division Review Committee Members:

H. U. Anderson, University of Missouri-Rolla, Rolla, MO

E. R. Beaver, Monsanto Company, St. Louis, MO

D. L. Douglas, Consultant, Bloomington, $\mathrm{MN}$

R. K. Genung, Oak Ridge National Laboratory, Oak Ridge, TN

J. G. Kay, Drexel University, Philadelphia, PA

R. A. Osteryoung, North Carolina State University, Raleigh, NC

G. R. St. Pierre, The Ohio State University, Columbus, OH

T. A. Baillieul, Battelle Columbus Laboratories, Columbus, $\mathrm{OH}$ 
P. Baisden, Lawrence Livermore National Laboratory, Livermore, CA

D. A. Bass, Doctor's Data, Inc., West Chicago, IL

T. Beasley, U.S. Environmental Measurements Lab., New York, NY

R. E. Berkeley, U.S. Environmental Protection Agency, Research Triangle Park, NC

R. Bisping, Fluor Daniel Hanford Inc., Richland, WA

R. B. Chessmore, GEOTECH/GJPO, Grand Junction, CO

N. F. Christopher, Martin Marietta Energy Systems, Piketon, $\mathrm{OH}$

J. S. Crain, Union Carbide Corporation, South Charleston, WV

P. T. Cunningham, Los Alamos National Laboratory, Los Alamos, NM

J. L. Daniel, Battelle Pacific Northwest Laboratory, Richland, WA

H. J. Dewey, USDOE, Office of Basic Energy Sciences, Germantown, MD

J. G. Dorsey, Lockheed Martin Energy Systems, Inc., Oak Ridge, TN

P. A. Duhamel, USDOE, Office of Health and Environmental Research, Germantown, MD

A. Edelman, USDOE, Office of Energy Research, Germantown, MD

C. Elly, U.S. Environmental Protection Agency, Chicago, IL

R. B. Fitts, Oak Ridge National Laboratory, Oak Ridge, TN

I. M. Fox, Woodridge, IL

C. W. Frank, USDOE, Office of Science and Technology, Washington, DC

J. Goldstein, USDOE, Office of Health and Environmental Research, Germantown, MD

B. T. Gregg, Allied Signal - Kansas City Division, Kansas City, MO

T. Grumbly, USDOE, Office of the Under Secretary, Washington, DC

J. K. Hancock, USDOE, Office of Pollution Prevention, Germantown, MD

G. A. Hansen, U.S. Environmental Protection Agency, Washington, DC

D. Hunter, Radiological Laboratories, Golden, $\mathrm{CO}$

J. T. Kiely, Doctor's Data, Inc., West Chicago, IL

W. Killian, Ferris State University, Big Rapids, MI

A. G. King, Lockheed Martin Hanford Company, Richland, WA

C. S. Leasure, Los Alamos National Laboratory, Los Alamos, NM

J. Mahoney, West Valley Nuclear Services Company, West Valley, NY

S. Messenger, Morton Arboretum, Lisle, IL

R. W. Morrow, Lockheed Martin Energy Systems, Inc., Oak Ridge, TN

L. Newman, Brookhaven National Laboratory, Upton, NY

R. D. Oldham, New Brunswick Laboratory, Argonne, IL

M. Pennington, Allied Signal Aerospace, Kansas City, MO

J. R. Phillips, Los Alamos National Laboratory, Los Alamos, NM

J. D. Pleil, U.S. Environmental Protection Agency, Research Triangle Park, NC

G. D. Robbins, Lockheed Martin Energy Systems, Inc., Oak Ridge, TN

J. B. Schilling, Southern Adventist University, Collegedale, TN

R. S. Scott, USDOE, Office of Environmental Management, Washington, DC

J. Q. Searcy, Sandia National Laboratories, Albuquerque, NM

J. Smith, University of Chicago, Chicago, IL

W. A. Spencer, Westinghouse Savannah River Company, Aiken, SC

F. D. Stevenson, USDOE, Office of Basic Energy Sciences, Germantown, MD

C. Stroup, Lockheed Martin Hanford Company, Richland, WA

L. Sygitowicz, Reynolds Electrical \& Engineering Co., Las Vegas, NV

R. Villarreal, Los Alamos National Laboratory, Los Alamos, NM

W. M. Walsh, Health Research Institute, Naperville, IL

R. J. Wingender, Dexter Corporation, Waukegan, IL 
M98004879


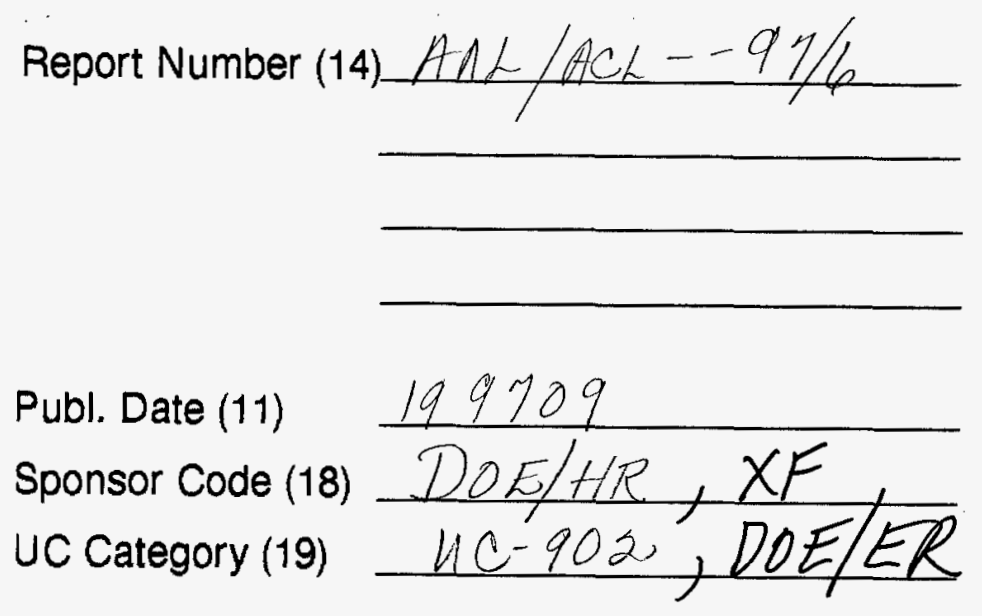